\title{
Roles of the immune system in cancer: from tumor initiation to metastatic progression
}

\author{
Hugo Gonzalez, Catharina Hagerling, ${ }^{1}$ and Zena Werb \\ Department of Anatomy, the Helen Diller Family Comprehensive Cancer Center, University of California at San Francisco, \\ San Francisco, California 94143, USA
}

The presence of inflammatory immune cells in human tumors raises a fundamental question in oncology: How do cancer cells avoid the destruction by immune attack? In principle, tumor development can be controlled by cytotoxic innate and adaptive immune cells; however, as the tumor develops from neoplastic tissue to clinically detectable tumors, cancer cells evolve different mechanisms that mimic peripheral immune tolerance in order to avoid tumoricidal attack. Here, we provide an update of recent accomplishments, unifying concepts, and future challenges to study tumor-associated immune cells, with an emphasis on metastatic carcinomas.

Cancer remains a major cause of death worldwide, and, with an aging population, its annual toll of 8.2 million is only expected to increase (Ferlay et al. 2015). In this respect, carcinomas can be broadly divided into two groups: metastatic (the principal cause of cancer-related deaths) and nonmetastatic (Siegel et al. 2016). Traditionally, metastasis has been considered to occur in later stages of cancer progression; however, accumulating evidence has also described metastatic dissemination during early tumor formation (Hosseini et al. 2016). During metastasis, disseminating cancer cells escape from primary tumors and acquire cellular traits that allow them to travel and colonize distant organs (Chambers and Werb 2015; Lambert et al. 2017; Gonzalez et al. 2018).

Primary and metastatic tumors are complex ecosystems composed of neoplastic cells, extracellular matrix (ECM), and "accessory" nonneoplastic cells, which include resident mesenchymal support cells, endothelial cells, and infiltrated inflammatory immune cells. Crosstalk between cancer cells and accessory cells fuels and shapes tumor development. During tumor formation, the

[Keywords: disseminated tumor cells; tumor-associated macrophages; metastasis-associated immune cells; patient-derived xenograft; immune cross-talk; cancer heterogeneity]

${ }^{1}$ Present address: Department of Clinical Genetics, Lund University, SE-221 85 Lund, Sweden.

Corresponding author: zena.werb@ucsf.edu

Article is online at http://www.genesdev.org/cgi/doi/10.1101/gad.314617. 118 . tissue architecture evolves into a highly specialized microenvironment characterized by a corrupted ECM and chronic inflammation (Coussens and Werb 2002).

Cancer-associated inflammation, which is present at different stages of tumorigenesis, contributes to genomic instability, epigenetic modification, induction of cancer cell proliferation, enhancement of cancer anti-apoptotic pathways, stimulation of angiogenesis, and, eventually, cancer dissemination (Hanahan and Weinberg 2011). Studies during the last two decades have demonstrated that inflammatory immune cells are essential players of cancer-related inflammation. Efforts have focused on understanding how immune cells impact tumor fate in different stages of disease: early neoplastic transformation, clinically detected tumors, metastatic dissemination, and therapeutic intervention. In this review, we focus on recent results, unifying concepts, limits, and futures challenges in studying cancer-associated inflammatory cells, with an emphasis on metastatic carcinomas.

\section{Cancer-related inflammatory conditions}

Since 1863, when Virchow first hypothesized that cancer develops as the product of unresolved inflammation (Balkwill and Mantovani 2001), tumor-associated inflammation has been key to shaping our modern understanding of cancer progression (Fig. 1). Today, it is accepted that chronic inflammation is a critical hallmark of cancer, with at least $25 \%$ of cancers associated with it (Hussain et al. 2000; Coussens and Werb 2002; Beaugerie et al. 2013), and possible underlying causes include microbial infections, autoimmunity, and immune deregulation. For example, human papilloma viruses (HPVs) induce inflammation and are responsible for $90 \%-100 \%$ of all cervical cancers (Bosch et al. 2002). Similarly, chronic infection with Helicobacter pylori elevates the risk for gastric

(C) 2018 Gonzalez et al. This article is distributed exclusively by Cold Spring Harbor Laboratory Press for the first six months after the full-issue publication date (see http://genesdev.cshlp.org/site/misc/terms.xhtml). After six months, it is available under a Creative Commons License (Attribution-NonCommercial 4.0 International), as described at http://creativecommons.org/licenses/by-nc/4.0/. 


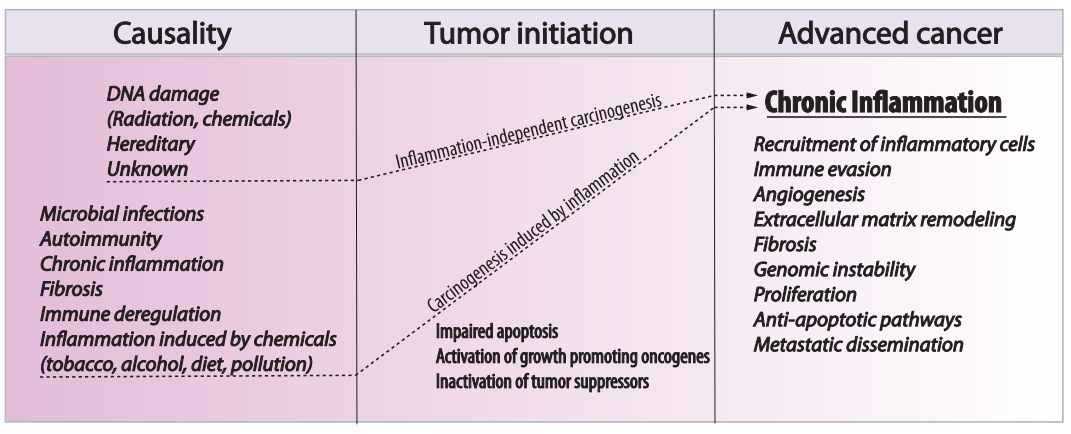

Figure 1. Chronic inflammation is a necessary consequence of cancer progression. Different inflammatory conditions can lead to neoplastic transformation. However, whether or not the inflammation is present in the origin of carcinogenesis, most tumors progress to a state of chronic inflammation that fuels different aspects of tumor progression, including genomic and epigenomic instability, immune evasion, angiogenesis, and metastatic dissemination. cancer (Hussain et al. 2000). In addition, the immune deregulation seen in inflammatory bowel disease increases colorectal cancer incidence (Lakatos and Lakatos 2008). The nonhuman form of sialic acid- $\mathrm{N}$-glycolylneuroaminic acid (Neu5Gc) - in red meat can be incorporated into human tissue and recruit inflammatory cells (Samraj et al. 2015). In this sense, diet may play a causal role in induction of cancer-associated inflammation (Gupta et al. 2010). Importantly, tobacco and obesity, both of which induce low-grade inflammation, give rise to elevated risks of cancer (Howe et al. 2013); this evidence suggests that the majority of cancers is associated with unresolved inflammation.

While chronic inflammation has an important role in cancer, less is known about the impact of acute inflammation on tumor progression. For example, inducing acute inflammation locally in the bladder with a vaccine containing an attenuated Mycobacterium bovis strain successfully treats squamous cancer of the bladder (Askeland et al. 2012). Hence, with the infiltration of leukocytes and subsequent inflammation, the impact from inflammatory mediators can both initiate and, in certain cases, eliminate tumor cells and prevent tumor development (Shalapour and Karin 2015). This dual role of inflammation also becomes evident in the clinic, where immunodeficient patients are more often diagnosed with cancer (Frisch et al. 2001). Interestingly, long-term use of nonsteroidal anti-inflammatory drugs (NSAIDs), which suppresses the immune system, has been linked to a lower risk of cancer (Thun et al. 2002).

Whether or not inflammation is a cause or a consequence, the tumor microenvironment (TME) is compromised, triggering an immune inflammatory response, and histopathological analyses provide evidence for the presence of innate and adaptive immune cells in most human tumors, which are characterized as features of cancer progression (Fridman et al. 2012).

\section{Role of inflammatory cells during cancer progression}

The presence of tumor-associated inflammatory cells in tumors raises an important question, which is one of the most important challenges in oncology: How do cancer cells avoid destruction by the immune system? Since inflammatory cells were first observed in human tumors, much effort has been invested in better understanding the complex role of inflammatory cells in carcinomas. It is currently accepted that an aberrant innate and adaptive immune response contributes to tumorigenesis by selecting aggressive clones, inducing immunosuppression, and stimulating cancer cell proliferation and metastasis (Fig. 2; Palucka and Coussens 2016). During the early stages of tumor development, cytotoxic immune cells such as natural killer $(\mathrm{NK})$ and $\mathrm{CD}^{+} \mathrm{T}$ cells recognize and eliminate the more immunogenic cancer cells (Teng et al. 2015). This first phase of elimination selects the proliferation of cancer cell variants that are less immunogenic and therefore invisible to immune detection. As the neoplastic tissue evolves to a clinically detectable tumor, different subsets of inflammatory cells impact tumor fate. For example, high levels of tumor-infiltrated T cells correlate with good prognosis in many solid cancers (Clemente et al. 1996; Oldford et al. 2006; Dieu-Nosjean et al. 2008); on the other hand, high levels of macrophage infiltration correlate with a worse prognosis (Zhang et al. 2012;

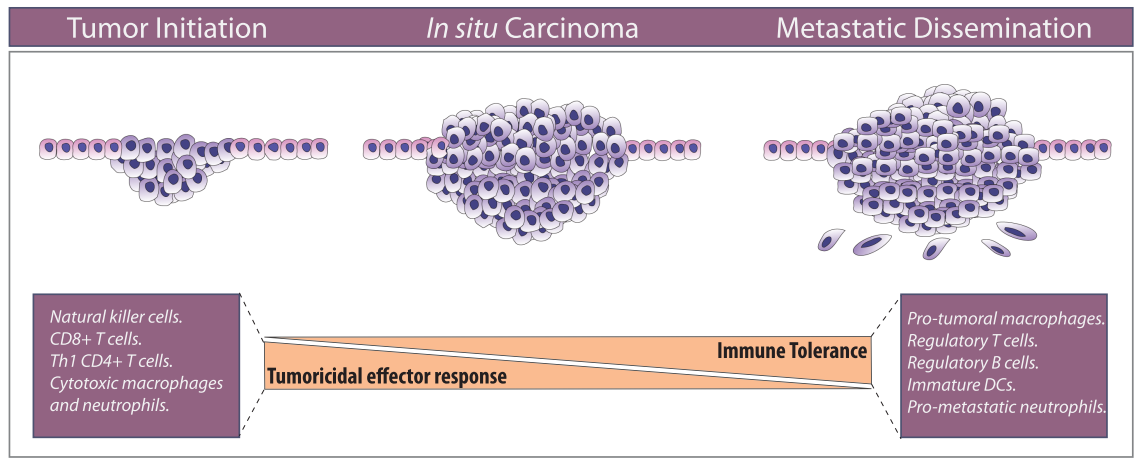

Figure 2. The balance between effector and tolerogenic immune response dictates tumor fate. During the early stages of tumor development, effector immune cells eliminate immunogenic cancer cells. Selected cancer cells that survive progress to clinically detectable tumors adopt different strategies of peripheral immune tolerance and recruitment of immunosuppressive immune cells that can subdue other tumoricidal cells. For abbreviations and further details, see the text. 
Mantovani et al. 2017; Gonzalez et al. 2018). Here, we review the important aspects and different facets of cancer-associated immune cells, focusing on progression from tumor initiation to metastatic colonization

\section{Macrophages}

Macrophages are innate immune cells that differentiate from circulating classical monocytes after extravasation into tissues. Upon differentiation, macrophages are equipped to sense and respond to infections and tissue injuries, playing a key role in tissue homeostasis and repair (Lavin et al. 2015). As crucial drivers of chronic cancer-associated inflammation, their involvement has been described in every step of cancer progression, from early neoplastic transformation throughout metastatic progression to therapy resistance (Fig. 3; Noy and Pollard 2014; Kitamura et al. 2015; Gonzalez et al. 2018). In oncological patients and preclinical experimental models, high-grade tumor-associated macrophages (TAMs) correlate with poor prognosis and reduced overall survival (Zhang et al. 2012; Noy and Pollard 2014).

Activated macrophages are referred to as either proinflammatory ("M1 type," driven by LPS and IFN $\gamma$ ) or anti-inflammatory ("M2-type," driven by IL-4 or IL-13) (Mantovani et al. 2002). During carcinogenesis, antitumor macrophages display an M1-like polarization that plays a relevant role in the elimination of more immunogenic cancer cells. As the tumor progresses, the TME elicits an M2-like polarization of TAMs that is protumorigenic (Mantovani et al. 2017). TAMs promote tumor progression in different ways, such as stimulating angiogenesis and lymphangiogenesis, stimulating both cancer cell proliferation and epithelial-mesenchymal transition, limiting the efficacy of therapies, remodeling the ECM, promoting metastasis, and inducing immunosuppression of anti-tumor effector immune cells (DeNardo et al. 2011; Qian et al. 2015; Mantovani et al. 2017). Accordingly, TAMs secrete cytokines such as IL-10 (Ng et al. 2013) and TGF- $\beta$ (McIntire et al. 2004) that induce immunosup- pression, impairing the activity of effector $\mathrm{T}$ cells and inhibition of dendritic cell (DC) maturation (Rubtsov et al. 2008). TAMs also directly stimulate cancer cell proliferation through the secretion of epidermal growth factor (EGF) (O'Sullivan et al. 1993), promote tumor angiogenesis by vascular EGF (VEGF) secretion (Shojaei et al. 2008), and remodel the ECM by secreting metalloproteinases (MMPs) (Kessenbrock et al. 2010). For example, macrophage-derived MMP-9 promotes tumorigenesis and angiogenesis (Huang et al. 2002).

Although TAMs mostly play protumorigenic roles, they can also sometimes exert anti-tumoral roles. For example, nonclassical NR4 $\mathrm{Al}^{+}$patrolling monocytes that, in steady state conditions, are located in the microvasculature of different organs inhibit lung metastasis in $M M T V$ PyMT mice by direct induction of NK cell recruitment to the metastatic site (Hanna et al. 2015). Additionally, TAMs mediate the efficacy of the anti-tumor and antimetastatic effects of the histone deacetylase inhibitor TMP195, which reprograms TAMs to a highly phagocytic phenotype (Guerriero et al. 2017).

Similar to other tumor-associated immune cells, TAMs have been described mostly in primary tumors. However, understanding the roles of macrophages as promoters or inhibitors in the metastatic cascade and their role in metastasis is a growing field. In xenograft models of breast cancer, TAMs regulate invasion of stroma and intravasation of cancer cells via cell contact-mediated signaling (Roh-Johnson et al. 2014). Circulating CCR $2^{+}$monocytes are attracted to metastatic sites by CCL 2 secreted by cancer cells and endothelial cells, resulting in promotion of metastatic seeding (Srivastava et al. 2014). In MMTVPyMT mice, Tie $2^{+}$metastasis-associated macrophages (MAMs) enhance angiogenesis and tumor proliferation, while the inhibition of angiogenesis by blocking of angiopoetin- 2 inhibits metastatic burden and induces regression of established metastases (Mazzieri et al. 2011). In a Kras-driven mouse model of pancreatic cancer, exosomes derived from malignant lesions induce activation of tissue-resident macrophages called Kupffer cells, establishing a premetastatic inflammatory milieu in the liver.

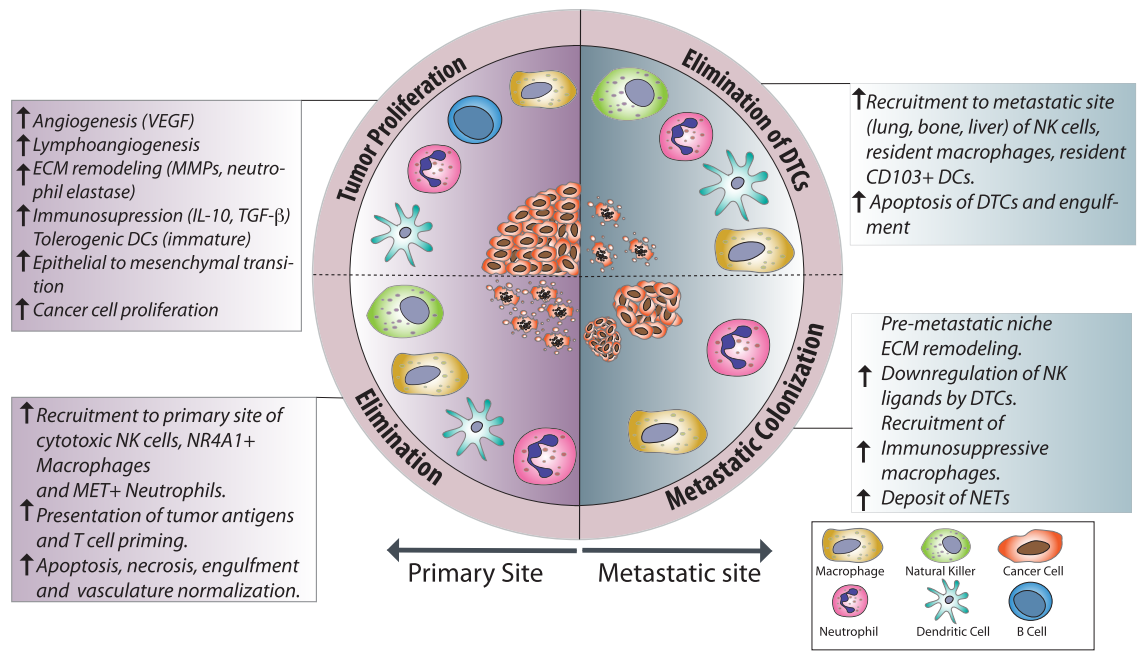

Figure 3. Roles of innate immune cells in metastatic cancers. An overview of the protumor and anti-tumor roles of innate immune cells in cancer, indicating the specific functions and the outcomes. Processes such as angiogenesis, ECM remodeling, and immune evasion are mediated by TAMs, tumor-associated neutrophils (TANs), and immature dendritic cells (DCs), resulting in rapid tumor progression and metastasis. In contrast, the recruitment of cytotoxic macrophages and neutrophils, NK cells, and mature DCs results in elimination of tumor cells in primary sites and after dissemination. (DTC) Disseminated tumor cell. For other abbreviations and further details, see the text. 
This is followed by subsequent arrest of bone marrowderived macrophages and neutrophils in the liver, resulting in a prometastatic effect, reversible by macrophage ablation (Costa-Silva et al. 2015).

TAMs are recruited to the tumors by a range of chemokines, including CCL2 (Nakatsumi et al. 2017), VEGF (Qian et al. 2011), CCL5 (Halama et al. 2016), and CSF1 (Abraham et al. 2010). The role of VEGF as a proangiogenic and protumor factor is well established and accepted; for example, VEGF ablation in monocytes decreases metastatic burden in experimental breast cancer metastasis (Qian et al. 2011). The role of CCL2 in cancer is more controversial, as previous studies have shown contradictory findings (Rollins and Sunday 1991; Manome et al. 1995; Lu and Kang 2009; Takahashi et al. 2009; Granot et al. 2011; Qian et al. 2011; Bonapace et al. 2014; Espinosa et al. 2014; Headley et al. 2016; Long et al. 2016). The inhibition of CCL2 in a syngeneic xenograft model of breast cancer results in increased metastasis and accelerated death (Bonapace et al. 2014), while tumor-derived CCL2 results in the induction of anti-metastatic neutrophils in an $M M T V-P y M T$ model, resulting in inhibition of metastatic seeding in premetastatic lungs (Granot et al. 2011). Furthermore, the increase of CCL2 in a 4T1 breast cancer model negatively regulates metastatic spread to the bone marrow and lungs (Takahashi et al. 2009). Using similar approaches, such as MMTV-PyMT and xenograft models of breast cancer, high CCL2 expression correlates with increased infiltration of CCR2 macrophages in primary tumors and metastatic sites, including the lungs and bone, and is associated with poor prognosis ( $\mathrm{Lu}$ and Kang 2009; Qian et al. 2011). These apparent contradictions cannot be explained merely by genetic differences between preclinical models used and highlight the complex role of CCR2 in the TME and likely heterogeneity in phenotypes within CCR2 ${ }^{+}$TAMs/MAMs. This dichotomy highlights the necessity of validating these findings in more reliable models that better represent human tumors of cancer, such as humanized patient-derived xenograft (PDX) models, and interrogating, at the singlecell level, the diversity of TAMs/MAMs in human tumors. Likewise, although the M1-like/M2-like paradigm has proved to be useful, transcriptomic analysis suggests that it is likely that a spectrum of differentiated TAMs/ MAMs exists and that the current model is oversimplified (Xue et al. 2014).

\section{Neutrophils}

Neutrophils are recognized as key players during inflammation. They are among the first immune cells to be recruited to damaged tissue, where they can eliminate pathogens and modulate inflammation by mechanisms such as phagocytosis, secretion of antibacterial proteins, deposit of neutrophil extracellular traps (NETs), and exocytosis of protease-containing granules (Kolaczkowska and Kubes 2013). In cancer patients, high levels of tumor-associated neutrophils (TANs), high levels of neutrophilia, and/or high neutrophil/lymphocyte ratios have been associated with an adverse prognosis in different malignances (Keizman et al. 2012; Donskov 2013). Similar to the M1/M2 phenotype of macrophages, it has been proposed that TANs exist in two polarization states, called "N1" and "N2," to describe protumor and anti-tumor populations, respectively (Fridlender et al. 2009). This paradigm is still a matter of debate due to the lack of specific markers to identify these two populations. However, it is clear that TANs display functional heterogeneity. The recruitment of TANs to the TME is thought be mediated mainly by CXCR2 ligands such as CXCL1, CXCL2 and CXCL5 (Jamieson et al. 2012; Katoh et al. 2013), secreted by cancer and stromal cells; TGF- $\beta$ has also been associated with recruitment and reprogramming to protumor TANs (Fridlender et al. 2009).

In xenograft models of melanoma and lung cancer, TANs expressing hepatocyte growth factor receptor (c-MET) play important anti-tumor and anti-metastatic roles. Interestingly, c-MET expression is induced by tumor-derived tumor necrosis factor- $\alpha$ (TNFa) (Finisguerra et al. 2015), and it is likely that NK and effector T cells are a source of TNF- $\alpha$ within the TME. Similarly, in human colorectal cancer, high levels of $\mathrm{CD} 6 \mathrm{~b}^{+}$TANs have been associated with better prognosis by enhancing the tumoricidal capacity of $\mathrm{CD}^{+} \mathrm{T}$ cells (Governa et al. 2017). Neutrophils also exert a tumoricidal function during radiotherapy. As they are rapidly and transiently recruited to tumor sites in syngeneic xenograft breast cancer models, the concurrent administration of granulocyte colony-stimulating factor (G-CSF) enhances radiotherapy effectiveness (Takeshima et al. 2016).

In contrast, TANs are thought to contribute to nascent inflammation during cancer initiation and progression. In a Kras-driven lung adenocarcinoma mouse model, IL-17-responsive TANs promote tumor growth /Chang et al. 2014). Also, neutrophil elastase acts as a potent elastolytic enzyme that, when secreted in a site of inflammation, promotes tumor cell invasion, angiogenesis, and cancer cell proliferation (Houghton et al. 2010; Gong et al. 2013). Moreover, TANs contribute to the tumor angiogenesis by the secretion of MMP9 and VEGF in genetic mouse models of pancreatic and colon cancer (Bergers et al. 2000; Shojaei et al. 2007, 2008). In gastric cancer, TANs induce direct immunosuppression in $\mathrm{T}$ cells by PD-L1 expression induced by tumor-derived granulocyte macrophage-CSF (GM-CSF) (Wang et al. 2017). A population of cells phenotypically and morphologically similar to neutrophils, called polymorphonuclear myeloid-derived suppressor cells (PMN-MDSCs), has been identified in cancer patients and preclinical models (for review, see Gabrilovich 2017). The presence of PMN-MDSCs in tumors is associated with induction of chronic inflammation and antigen-specific tolerance by T cells (Marigo et al. 2010). Using the MMTV-PyMT transgenic breast cancer model, we described that the production of tumor-derived G-CSF during tumor progression induces the systematic differentiation and activation of PMN-MDSCs, characterized by CD11b+ Rb1lo Ly6G ${ }^{+}$(Casbon et al. 2015).

Neutrophils have been proposed to be pioneer cells in the lung premetastatic niche, supporting the arrival of 
disseminated cells in the MMTV-PyMT model (Wculek and Malanchi 2015). Moreover, in response to the secretion of IL-7 by $\gamma \delta$ T cells, neutrophils are recruited to the lungs, where they support the survival and proliferation of disseminated cancer cells by suppressing effector $\mathrm{CD}^{+} \mathrm{T}$ cells (Coffelt et al. 2015). This prometastatic motif is also seen during liver metastasis in the KPC model of pancreatic cancer (Steele et al. 2016). These results demonstrate that the protumor and anti-tumor functions of TANs are highly context-dependent and likely depend on immune cross-talk with other tumor-associated immune cells.

In recent years, the presence of NETs in the TME has been linked to cancer progression in animal models and cancer patients (Cools-Lartigue et al. 2013, 2014; Tohme et al. 2016), NETs are extracellular networks released by neutrophils-composed mostly of chromatin, proteases (such as elastase, cathepsin G, and MMP9), and intracellular proteins-that immobilize pathogens to facilitate their subsequent elimination (Papayannopoulos 2018). An increase in NET formation has been correlated with progression to metastatic disease in colorectal cancer patients after surgery (Tohme et al. 2016). Additionally, NETs trap circulating cancer cells, increasing the adhesion within hepatic sinusoids, which favors extravasation and parenchyma colonization (Cools-Lartigue et al. 2013). In breast cancer, NETs accumulate around metastatic cells that have reached the lungs of mice. Notably, targeting NETs in vivo with DNase I-coated particles reduces metastatic burden (Park et al. 2016). NETs seem to play a protumor role by the direct activity of NET-derived proteases and also by holding cancer cells in place, likely facilitating the concentration and localization of cancer effectors that result in increased degradation of the ECM, migration, and invasion (Cools-Lartigue et al. 2014).

There is a growing recognition of neutrophils as relevant players at different steps of cancer progression; however, a better characterization of the phenotypic heterogeneity and plasticity of cancer-associated neutrophils is needed, considering that they are the most abundant immune cells in circulation. The understanding of where and how the neutrophils are programmed or reprogrammed to be protumor and/or anti-tumor will lead to rational designing of targeted therapies.

\section{NK cells}

NK cells are innate immune cells that display rapid and potent cytolytic activity in response to infected or transformed cells (Cerwenka and Lanier 2016). NK cells have a wide array of inhibitory and stimulatory receptors on their cell surface that are used for immune surveillance. The inhibitory receptors target cancer cells lacking major histocompatibility class I (MHC-I), marking them for programmed cell death (Marcus et al. 2014). In contrast, in healthy cells, the binding of MHC-I molecules to their receptors on NK cells has a profound inhibitory effect on NK cell function (Bix et al. 1991; Liao et al. 1991; Colonna et al. 1992; Karlhofer et al. 1992; Wagtmann et al. 1995;
Lanier 2005). NK cells have a well-documented antitumor effect (Marcus et al. 2014; Iannello et al. 2016). In this regard, the presence of NK cell infiltration in colorectal (Coca et al. 1997) and gastric (Ishigami et al. 2000) tumors correlates with a favorable outcome. Hence, there appears to be an intricate link between incipient tumor transformation and the ability of innate immune cells to recognize it. Indeed, in mice, aberrant cell proliferation induces production of the ligand retinoic acid early transcript 1 (RAE1), which is recognized by the stimulatory receptor NKG2D, expressed on NK cells (Raulet et al. 2013). Besides aberrant cell proliferation, DNA damage (Gasser et al. 2005) and RAS pathway activation (Liu et al. 2012b) induce production of ligands in tumor cells, which are recognized by NKG2D on NK cells. In line with the important role of NKG2D for immune surveillance, mice deficient in NKG2D receptor are more susceptible to tumor development (Guerra et al. 2008). Besides NKG2D, NK cells have a repertoire of different stimulatory cell surface receptors, which, upon binding to their tumor-derived ligands, activate NK cells (Cerwenka et al. 2000; Diefenbach et al. 2000, 2001; Raulet 2003). In a mouse model of hepatic carcinoma, the restoration of the tumor suppressor p53 in cancer cells promotes the elimination of senescent cells (Iannello et al. 2013). Upon activation, NK cells mediate the tumor killing mainly by releasing cytotoxic perforin (Voskoboinik et al. 2006) and granzyme, eliminating tumor cells and also triggering apoptotic pathways in tumor cells through the production of TNFa or via direct cell-cell contact through activation of the TRAIL and FASL pathways. Densely granulated NK cells are recruited into large solid tumors by tumor-produced IL-15, where they successfully eliminate established tumors (Liu et al. 2012a). The natural cytotoxicity receptor NKp46 and inhibitory receptor Ly49 on NK cells prevent metastatic outgrowth in melanoma, lung, and fibrosarcoma models (Andrews et al. 2012; Glasner et al. 2012). These data highlight the importance of NK cells' function in controlling cancer progression. Future efforts should be addressed to define the regulatory circuits of the innate and adaptive immunity that results in tumor killing by NK cells.

\section{DCs}

These specialized antigen-presenting cells (APCs) that represent the interface between innate and adaptive immunity are able to present endogenous and exogenous antigens to $\mathrm{T}$ cells in the context of MHC molecules. With the exception of the brain parenchyma, DCs are located in every tissue across the body (Mildner and Jung 2014). During tumor development, DCs prime naïve and memory $\mathrm{T}$ cells, and, depending on the inflammatory context and the costimulatory signals, the antigen presentation can result in antigen tolerance or priming and triggering of an effector T-cell response. Tumor-infiltrating DCs have been described in many cancer types (Tran Janco et al. 2015), and, although their activity is necessary to explain the role of $\mathrm{T}$ cells during cancer 
progression, DC involvement in cancer progression remains understudied.

Insights into DC mechanisms are limited. A mouse model of fibrosarcoma lacking $\mathrm{CD} 8 \mathrm{a}^{+}$DCs shows impaired tumor rejection mediated by $\mathrm{CD}^{+}$and $\mathrm{CD}^{+}$ $\mathrm{T}$ cells (Hildner et al. 2008). This anti-tumor effect of $\mathrm{CD} \mathrm{a}^{+}$DCs priming effector $\mathrm{T}$ cells is selectively dependent on type I interferon production (Diamond et al. 2011). CD $103^{+}$DCs have critical roles in tumor antigen presentation in transgenic and xenograft mouse models of melanoma and breast and cervical cancer (Broz et al. 2014; Moynihan et al. 2016; Roberts et al. 2016). During chemotherapy-induced anti-tumor immune responses, ATP and damage signals released by necrotic cells induce the recruitment of myeloid cells; this is followed by local differentiation to $\mathrm{CD} 11 \mathrm{c}^{+} \mathrm{CD} 11 \mathrm{~b}^{+}$Ly6 $\mathrm{C}^{\text {hi }}$ DCs that efficiently engulf tumor antigens in situ and prime the anti-tumor effector T-cell response (Ma et al. 2013). Mechanistically, the expression of formyl-peptide receptor 1 on DCs favors the recognition and stable interaction with dying cancer cells followed by maturation, engulfing, and antigen presentation in breast and colorectal cancer (Vacchelli et al. 2015). Intravital imaging analysis identified lung-resident $\mathrm{CD} 103^{+}$DCs as direct suppressors of metastatic melanoma cells (Headley et al. 2016). These findings highlight the essential role of DCs.

Between 1995 and 2004, several clinical trials in phases I, II, and II have tested the use of autologous DCs pulsed with tumor antigens (DC vaccine) to initiate an anti-tumor T-cell response, with promising but limited success, especially in melanoma and prostate cancer (Mukherji et al. 1995; Nestle et al. 1998; Beer et al. 2011). The limitations in the use of DC vaccines include ex vivo manipulation such as antigen loading, which impacts DC function in vivo, and also the lack of deep insights into DC subsets and their functional specialization in cancer (for review, see Santos and Butterfield 2018). More recently, a phase II study in 39 melanoma patients showed that the combination of an intradermal DC vaccine combined with CTLA-4 blockade resulted in eight complete and seven partial therapeutic responses (Wilgenhof et al. 2016). The combination of DC vaccines and the amplification of immunity by the use of checkpoint blockade (see "T cells" below) is an attractive strategy worthy of further testing.

Overall, DCs play a key role in the priming and consolidation of anti-tumor adaptive immune response; a better understanding of such mechanisms will shed light on how the anti-tumor T-cell attack fails to eliminate and contain the tumor development. In this sense, massive parallel single-cell analysis in early lung adenocarcinoma (stage I) has identified a selective depletion of $\mathrm{CD}_{141^{+}} \mathrm{DCs}$ (compared with normal lung tissue) that correlates with impaired NK and T-cell activity, which favors tumor progression (Lavin et al. 2017). Recently, it has been shown that in melanoma, breast, and colorectal mouse models, tumor cells impair DC recruitment to TME by secretion of prostaglandin E2, which impairs the function of tumor-associated NK cells and results in impaired NK cell-dependent DC recruitment (Bottcher et al. 2018).

\section{T cells}

$\mathrm{T}$ cells are components of the adaptive immune system that act as orchestrators and effectors of immunity. Depending on the immunological context, $\mathrm{T}$ cells can acquire functional and effector phenotypes whose activity has direct inflammatory or anti-inflammatory consequences (Speiser et al. 2016). As the second most frequent immune cell type found in human tumors besides TAMs, $\mathrm{T}$ cells are extensively studied in diverse cancer types (Speiser et al. 2016; Donadon et al. 2017). During the early stages of tumor initiation, if enough immunogenic antigens are produced, naïve $\mathrm{T}$ cells will be primed in the draining lymph nodes, followed by their concomitant activation and migration to the TME. From there, they mount a protective effector immune response, eliminating immunogenic cancer cells. Histopathological analyses of human tumors show that tumor-associated $\mathrm{T}$ cells extend beyond the invasive edge of the tumor and also predominate in its hypoxic core (Halama et al. 2011; Kirilovsky et al. 2016). A high level of T-cell infiltration in tumors is associated with a favorable prognosis in melanoma (Clemente et al. 1996) and breast (Oldford et al. 2006), lung (Dieu-Nosjean et al. 2008), ovarian (Kusuda et al. 2005), colorectal (Tosolini et al. 2011), renal (Kondo et al. 2006), prostate (Vesalainen et al. 1994), and gastric (Ubukata et al. 2010; Fridman et al. 2012; Kitamura et al. 2015) cancer.

$\mathrm{CD}^{+} \mathrm{T}$ cells are the most prominent anti-tumor cells. Upon priming and activation by APCs, the $\mathrm{CD} 8^{+} \mathrm{T}$ cells differentiate into cytotoxic $\mathrm{T}$ lymphocytes (CTLs) and, through the exocytosis of perforin- and granzyme-containing granules, exert an efficient anti-tumoral attack, resulting in the direct destruction of target cells (Hanson et al. 2000; Matsushita et al. 2012). Meanwhile, the $\mathrm{CD}^{+} \mathrm{T}$ helper 1 (Th-1)-mediated anti-tumoral response - through secretion of high amounts of proinflammatory cytokines such as IL-2, TNF- $\alpha$, and IFN- $\gamma$-promotes not only T-cell priming and activation and CTL cytotoxicity but also the anti-tumoral activity of macrophages and NK cells and an overall increase in the presentation of tumor antigens (Kalams and Walker 1998; Pardoll and Topalian 1998; Shankaran et al. 2001). The presence of tumor-infiltrating $\mathrm{CD}^{+} \mathrm{T}$ cells and Th-1 cytokines in tumors correlates with a favorable prognosis in terms of overall survival and a disease-free survival in many malignancies (Fridman et al. 2012).

If the $\mathrm{T}$ cells are highly effective at killing malignant transformed cells, how do some cancer cells manage to overcome the attack by these effector T cells? Preclinical investigations in patients and mouse models suggest that cancer cells exploit the immunosuppressive properties of $\mathrm{T}$ cells while impairing the effector functions of antitumor $\mathrm{T}$ cells, such as their ability to infiltrate tumors and their survival, proliferation, and cytotoxicity (Fig. 4; Grivennikov et al. 2010). The antigen-dependent nature of the effector $\mathrm{T}$ cells implies that the effectiveness of the anti-tumor T-cell immune response depends on both the ability of the tumor antigen to induce an immune response (immunogenic) and the presence-or absence-of 


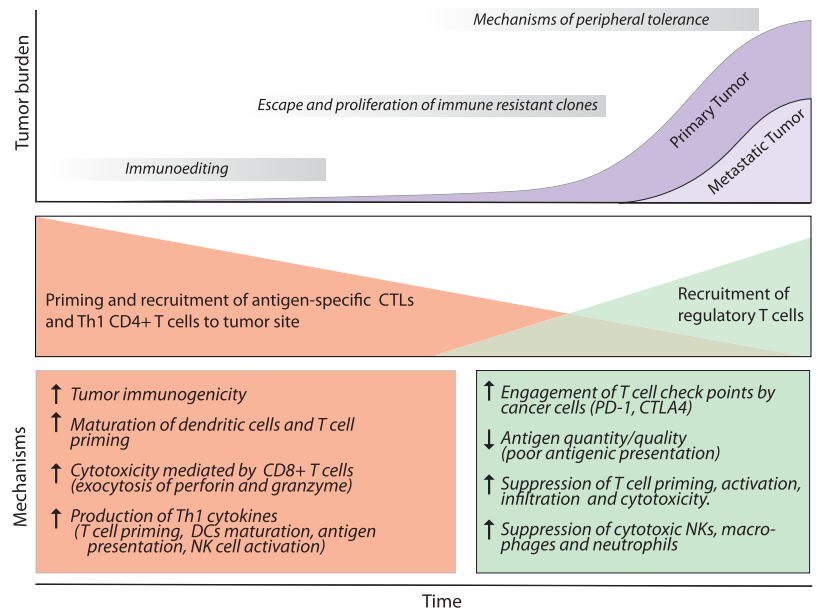

Figure 4. Dual role of $\mathrm{T}$ cells in cancer and metastasis. During the early stages of tumorigenesis, the T-cell response against tumor-derived antigens controls tumor progression, characterized by secretion of Th- 1 cytokines (IFN- $\gamma$, IL-2, and IL-12), NK cell recruitment, and the presence of CTLs. As a consequence of the constant selective pressure of the effector response, tumor variants are selected and escape immune recognition. These tumor cells enter a phase of outgrowth that is not blocked by effector immune cells. Concomitantly, the tumor induces the recruitment of regulatory $\mathrm{CD}^{+} \mathrm{T}$ cells (Tregs) that counteract anti-tumor immune cells by diverse mechanisms. Tumors with high infiltration of Tregs are associated with the worst prognosis. For abbreviations and further details, see the text.

inhibitory signals that can impair the $\mathrm{T}$ cells' functions (Speiser et al. 2016). Accordingly, it is widely accepted that, in a T-cell-dependent process, most neoplastic cells expressing highly immunogenic antigens will be recognized and killed during the early stages of tumor development (Matsushita et al. 2012). The less immunogenic cancer cells escape the immune control of $T$ cells and survive, a process termed cancer immune editing (Teng et al. 2015). The final outcome is that the surviving cancer cells adopt an immune-resistant phenotype. In parallel, during tumor development, cancer cells evolve mechanisms that mimic peripheral tolerance and are able to prevent the local cytotoxic response of effector T cells as well as those of other cells, such as TAMs, NK cells, and TANs (Palucka and Coussens 2016).

During immune homeostasis, a crucial mechanism of peripheral tolerance is the regulation of effector T-cell response via immune checkpoints on CTLs and activated $\mathrm{CD}^{+} \mathrm{T}$ cells to protect tissue from inflammatory damage. The two better described checkpoint molecules CTLA-4 and PD-1 act as negative regulators of T-cell function and have been associated with immune evasion in cancer (Pardoll 2012). The involvement of CTLA-4 signaling in cancer has been described in melanoma (Bouwhuis et al. 2010) and lung (Khaghanzadeh et al. 2010), breast (Erfani et al. 2006), gastric (Hadinia et al. 2007), and colorectal (Hadinia et al. 2007; Dilmec et al. 2008) cancer. Furthermore, the engagement of PD1 with its coreceptor, PDL-1 (expressed by other immune cells, mesenchymal cells, vascular cells, and cancer cells), results in the down-regulation of T-cell activity, which inhibits their anti-tumor activities such as T-cell migration, proliferation, secretion of cytotoxic mediators, and restriction of cell killing (Topalian et al. 2015). Over the past few years, the use of immune checkpoint inhibitors such as anti-PD1 (pembrolizumab and nivolumab), anti-PD-L1 (MPDL3280A), and anti-CTLA4 (ipilimumab) has had remarkable success enhancing the effector anti-tumor response in different malignancies (Gotwals et al. 2017), especially in melanoma and lung cancer (Hamid et al. 2013; Herbst et al. 2014; Topalian et al. 2015).

As the tumor grows and the TME changes, new antigens are produced, and the ability of the immune system to prime new repertoires of $\mathrm{T}$ cells and direct them toward the tumor changes, thus altering the efficacy of tumor containment. As the immune system functions to stall tumor growth, cancer cells and the TME simultaneously suppress anti-tumor function by engaging immune checkpoints and the recruitment of regulatory $\mathrm{CD}^{+} \mathrm{T}$ cells (Tregs). Tregs are responsible for suppressing the priming, activation, and cytotoxicity of other effector immune cells, such as Th1 CD4 T cells, CTLs, macrophages, NK cells, and neutrophils (Ward-Hartstonge and Kemp 2017). The Treg-mediated immunosuppression is orchestrated by contact-dependent mechanisms such as the expression of PDL-1, LAG-3, CD39/73, CTLA4, or PD1, with the latter two even enhancing suppressive activity (Walker and Sansom 2015), and by contact-independent mechanisms, which involve the sequestration of IL-2 and production of immune-suppressive molecules such as IL-10, TGF- $\beta$, prostaglandin E2, adenosine, and galectin-1 (Francisco et al. 2009; Campbell 2015). In squamous cell carcinoma, the inhibition of focal adhesion kinase (FAK) — a cell contact-independent mechanism-results in CCL 5 secretion by cancer cells that induces the recruitment of Tregs to the tumor site, where they suppress the cytotoxic anti-tumor $\mathrm{CD} 8^{+} \mathrm{T}$ cells (Serrels et al. 2015). In breast and lung adenocarcinoma, Tregs suppress T-cell activation and the anti-tumor immune response in tumor-associated tertiary structures. Notably, specific Treg depletion results in tumor cell death and increased production of IFN- $\gamma$ (Bos et al. 2013; Joshi et al. 2015). Indeed, infiltration of Tregs in breast cancer was correlated recently with worse patient outcome (Allaoui et al. 2017).

In metastasis, CTLs exert an anti-metastatic effect in bone metastasis (Bidwell et al. 2012), while prospective analyses of lung and breast cancer patients established an opposite correlation between the level of circulating cancer cells and $\mathrm{T}$ cells in peripheral blood (Mego et al. 2016; Sun et al. 2017). These data extend to clinical trials reporting the therapeutic efficacy of immune checkpoint inhibition in metastatic carcinomas (Di Giacomo et al. 2012; Queirolo et al. 2014; Motzer et al. 2015; Furudate et al. 2016; Goldberg et al. 2016; Pai-Scherf et al. 2017). Interestingly, checkpoint inhibitors are significantly effective in treating brain metastatic tumors from melanoma and lung cancer, especially when considering the lack of the adaptive immune response in the central 
nervous system (Queirolo et al. 2014; Goldberg et al. 2016; Di Giacomo et al. 2017). Recent evidence suggests that the effectiveness of checkpoint inhibition in melanoma brain metastasis depends on extracranial disease and peripheral activation of $\mathrm{CD}^{+} \mathrm{T}$ cells (Taggart et al. 2018). On the other hand, a high level of circulating Tregs has been associated with a higher risk of metastasis in nonsmall lung carcinoma patients. (Erfani et al. 2012). Similar associations have been described in breast cancer (Metelli et al. 2016), colorectal carcinoma metastasis (Wang et al. 2014), and hepatocellular carcinoma (Ye et al. 2016).

The cutting-edge technology of immunotherapy boasts impressive clinical potential and poses an opportunity to exploit the antigen specific T-cell attack to fight cancer. The challenge faced now is to better understand the mechanisms that cancer cells undergo to evade T-cell attack. Also, elucidating the mechanisms that mediate the generation of antigenic heterogeneity of tumors will lead to defining better immunotherapies for patients, expanding access to therapies to already metastasized patients.

\section{Invariant NK T (iNKT) cells}

An unconventional subset of T cells, iNKT cells, recognizes lipid antigens presented by CD1d molecules and shares some characteristics with NK cells, among which is the potential for activation in the absence of TCR stimulation. Upon activation, iNKT cells secrete effector cytokines such as IFN- $\gamma$, IL-4, and IL-17 (Lee et al. 2015). In breast cancer cells, the down-regulation of CD1d leads to decreased iNKT-mediated cytotoxicity and metastatic progression (Hix et al. 2011). However, in renal cell carcinoma patients, the expression of CD1b is associated with high relapse and poor prognosis (Chong et al. 2015). The administration of retinoic acid and aGalCer (iNKT agonist) alone or the transfusion of aGalCer-loaded DCs reduces the tumor size and the number of metastatic foci in a mouse model of breast cancer by enhancing $\mathrm{CD}^{+}$T-cell cytotoxicity (Chen and Ross 2012; Gebremeskel et al. 2015). A phase I-II study on patients with advanced lung cancer arrived at similar conclusions (Motohashi et al. 2009). These findings are remarkable in that they illustrate the impact of iNKT activation and how the monospecific nature of iNKT cells and the therapeutic use of aGalCer can be used to reprogram the anti-tumor immune response.

\section{B cells}

Upon activation in the germinal centers in lymphoid organs, B cells expressing high-affinity antibodies differentiate into antibody-secreting plasma cells and memory $B$ cells that mediate humoral immunity against pathogens (De Silva and Klein 2015). Although the presence of B cells in the TME has been described in different carcinomas (including melanoma and breast, ovarian, and prostate cancer, among others) (Chin et al. 1992; Yang et al. 2013; Woo et al. 2014; Pylayeva-Gupta et al. 2016), the role of $\mathrm{B}$ cells in cancer progression is much less understood than that of $\mathrm{T}$ cells. Accumulating evidence indicates that B cells promote and support tumor growth; for example, using a transgenic mouse model of epithelial carcinogenesis, Coussens and colleagues (de Visser et al. 2005) demonstrated that the lack of mature B cells decreases tumor progression. Notably, the adoptive transfer of B cells restores chronic inflammation, angiogenesis, and tumor growth. Different mechanisms have been described to explain the protumor role of B cells, from immunosuppression via secretion of IL-10 (Schioppa et al. 2011) and TGF $\beta$ (Olkhanud et al. 2011) to direct stimulation of tumor cell proliferation by B-cell-derived IL-35 in human pancreatic neoplasia and Kras-driven pancreatic neoplasms in mice (Pylayeva-Gupta et al. 2016). Also, by deposition of immunoglobulins in the TME, B cells indirectly stimulate angiogenesis and chronic inflammation by activating myeloid cells via FcR $\gamma$ (Andreu et al. 2010). It is unclear how many different phenotypes of B cells coexist in the TME or whether the B cells are recruited as immune suppressors or are reprogrammed into the TME. The subsets of $\mathrm{B}$ cells that induce immunosuppression are termed regulatory B cells due to their function, although there is no consensus about this classification due to the lack of specific markers, similar to FoxP3 and CD25 in Tregs.

\section{Cross-talk between immune cells sculpts the response to the tumor}

An aspect that has received less attention is the cross-talk between different immune cells within the TME and how it impacts the outcome of the subsequent immune response. There is growing evidence that tumor-associated immune cells act in concert to both control and promote the tumor formation. In this sense, during the phase of elimination, NK cells exert a strong tumoricidal role; secretion of CCL5 and XCL1 by NK cells promotes the recruitment of conventional DCs (cDCs) to the TME, resulting in increased priming and activation of new repertoires of anti-tumor $\mathrm{T}$ cells, stimulating the overall effector immune response (Moretta et al. 2005; Bottcher et al. 2018). Additionally, the reciprocal interplay between NK cells, effector $\mathrm{T}$ cells, and anti-tumor macrophages by the secretion of IFN- $\gamma$ and TNF- $\alpha$ in the tumor site boosts the differentiation of CTLs, increases macrophage phagocytosis, increases the recruitment of cytotoxic $\mathrm{cMET}^{+}$ neutrophils, and enhances the cytotoxic ability of NK cells (Finisguerra et al. 2015; Showalter et al. 2017). Dectin-1, a pattern recognition receptor on macrophages and DCs, recognizes N-glycan structures on tumor cells, which activate the IRF5 pathway responsible for enhancing the killing capacity of NK cells (Chiba et al. 2014). Moreover, CX3CR $-1^{+}$patrolling monocytes inhibit metastatic progression through the recruitment of NK cells to the metastatic site, and then NK cell-derived IFN- $\gamma$ reprograms macrophages into a tumoricidal effector macrophage state (O'Sullivan et al. 2012).

Once the tumors have escaped from initial tumoricidal immunity, they undergo different strategies that tip the 
balance toward immune tolerance, with the TAMs and tumor-associated Tregs as key orchestrators of this process, as they dampen the effect of innate and adaptive effector immune cells at various levels and through different mechanisms. For example, TAMs and Tregs boost an immune-tolerant TME by secretion of immune-suppressive molecules such as IL-10, TGF- $\beta$, and prostaglandins; they also inhibit the secretion of IL-12 by DCs, avoiding the mounting of a Th-1 response and excluding NK and effector T cells (Ruffell et al. 2014; Speiser et al. 2016; Frydrychowicz et al. 2017; Mantovani et al. 2017; Tauriello et al. 2018). Recently, a combination immunotherapyincluding a tumor antigen targeting antibody, a recombinant interleukin-2 with an extended half-life, anti-PD-1, and a T-cell vaccine-efficiently eliminated established large metastatic tumors in multiple cancer models; subsequent analysis showed that the efficacy was dependent on an orchestrated response of both innate and adaptive immune cells (Moynihan et al. 2016). These data further highlight the importance of therapies designed to stimulate an orchestrated immune effector response.

Understanding the in situ cross-talk of different tumorassociated immune cells in the different stages of cancer progression will provide insights that could increase the efficiency of current immunotherapies. Additionally, the use of massive single-cell genomic and proteomic data will allow a system-level view of the tumor-associated immune function in the years to follow.

\section{Cancer heterogeneity and anti-tumor immunosurveillance}

Analysis of human primary and metastatic tumors has shown high levels of genomic, phenotypic, and antigenic heterogeneity (Swanton 2012), which contribute to therapy failure and disease progression. This poses an arduous clinical and technical challenge (Bedard et al. 2013; Kreso and Dick 2014). Various mechanisms have been proposed to explain intratumor heterogeneity: Genomic instability (McGranahan and Swanton 2015), hierarchical organization arising from initiating cancer stem cells (Kreso and Dick 2014), and selective pressure imposed by the immune system likely impact antigen heterogeneity of the tumor (Quail and Joyce 2013). Through cancer immune editing, the immune system eliminates the more immunogenic cancer cells, thus promoting the development of clonal tumors and thereby decreasing the heterogeneity. In contrast, the lack of immune selection likely increases the neoantigen heterogeneity. Recent analysis of neoantigen heterogeneity in tumor samples from lung cancer and melanoma patients demonstrated that patients with clonal tumors ( $\sim 78 \%$ of clonality) are more susceptible to T-cell attack and have a more sensitive tumor checkpoint inhibition compared with more heterogeneous tumors ( 8\% of clonality) (McGranahan et al. 2016). Moreover, analysis of different areas of heterogeneous tumors showed different levels of antigen-specific CD8 ${ }^{+}$ $\mathrm{T}$ cells in different tumor regions (McGranahan et al. 2016). Increases in the mutational burden and heterogene- ity of neoantigens in vivo as well as the priming of new anti-tumor T-cell repertoires (Rizvi et al. 2015; Germano et al. 2017) result from the inactivation of the DNA repair system in colorectal, breast, and pancreatic cell lines. Interestingly, tumors with high neoantigen burden correlate with good prognosis in lung cancer patients treated with anti-PD1 (Rizvi et al. 2015).

As genomic tumor heterogeneity increases, so too does the probability of subclonal generations escaping immune attack. In this sense, metastatic progression and therapy resistance usually proceed from rare clones in primary tumors (Gupta and Massague 2006). Consistent with this view, a deep analysis of intrapatient metastases in a patient with ovarian cancer showed that regressing metastatic tumors were associated with an immune infiltrate characterized by $\mathrm{CD}^{+}$and $\mathrm{CD} 8^{+} \mathrm{T}$ cells and higher tumor mutation and neoepitope load compared with progressing lesions that are associated with T-cell exclusion (JimenezSanchez et al. 2017). This case study provides evidence of the clinical impact of the relationship between tumor heterogeneity and anti-tumor immune surveillance. It is unclear whether the cancer heterogeneity observed in patients is the end result the immune system's inability to stop tumor progression or whether the mutational burden promotes heterogeneity that leads to immune evasion. Furthermore, the evolving mutation burden, the selective pressure of chemotherapy, and the rapid turnover of inflammatory cells within the primary and metastatic tumor, in conjunction with the nonuniform distribution of immune cells throughout the tumor, likely promote differential selective pressures in disparate tumor regions, allowing for the development of heterogeneous tumors (McGranahan et al. 2016). The success of current immunotherapies depends on the ability of the immune system, particularly $\mathrm{T}$ cells, to recognize and eliminate tumors with multiclonal or subclonal neoantigens. These findings highlight the importance of better understanding the complex relationships between cancer cells and immune attack and how these relationships drive the development of cancer heterogeneity.

\section{How tumor cells evade the immune response}

Tumor cells evade the immune attack using two main strategies: avoiding the immune recognition and instigating an immunosuppressive TME. In the first, cancer cells may lose the expression of tumor antigens on the cell surface, thus avoiding the recognition by cytotoxic $\mathrm{T}$ cells. For example, $40 \%$ of non-small cell lung cancers hold a loss of heterozygosity in human leukocyte antigens (HLAs), which leads to immune escape by presenting fewer antigens (McGranahan et al. 2017). Notably, HLA loss has been associated with resistance to $\mathrm{T}$-cell transfer therapy in metastatic colorectal cancer (Tran et al. 2016) and poor outcome response to checkpoint blockade immunotherapy in melanoma and lung cancer patients (Chowell et al. 2018). In this sense, mutations and deletions may result in down-regulation of the antigen-presenting machinery and likely confer resistance to T-cell effector 
molecules such as TNF- $\alpha$ and IFN- $\gamma$ (Patel et al. 2017). Additionally, to overcome the attack of NK cells in experimental metastasis, breast and lung cancer cells downregulate cell surface NK activators, becoming invisible to detection by NK cells (Malladi et al. 2016).

In the second, cancer cell-derived factors instigate an immune-tolerant TME by (1) secretion of suppressive molecules such as IL-10, TGF- $\beta$, prostaglandin E2, and VEGF (Gabrilovich et al. 1996; Massague 2008; Dominguez-Soto et al. 2011; Bottcher et al. 2018); (2) expression of inhibitory checkpoint molecules such as PD-L1, CTLA4 , and V domain immunoglobulin suppressor of T-cell activation (VISTA) (Topalian et al. 2012; Snyder et al. 2014; Boger et al. 2017); and (3) induction of the recruitment of TAMs, MDSCs, and Tregs by tumor-derived chemokines such as CCL2, CSF1, CCL5, CCL22, CXCL5, CXCL8, and CXCL12 (Weitzenfeld and Ben-Baruch 2014; Kumar et al. 2016; Mantovani et al. 2017; Tanaka and Sakaguchi 2017). Combined, these strategies result in a complex and efficient system for immune evasion. Therefore, multimodal therapies aimed at disrupting different aspects of the immune-tolerant apparatus in cancer may improve the efficiency of current immunotherapies. In this regard, two studies showed recently that the TGF- $\beta$ blocking increases the therapeutic response of anti-PDL1 therapy, resulting in tumor regression in EMT6 breast carcinoma models (Mariathasan et al. 2018) and complete elimination of established liver metastases from a colorectal cancer model (Tauriello et al. 2018).

\section{Challenges in studying cancer-associated inflammatory cells}

Developing a reliable experimental model that accurately resembles the cancer-associated immune surveillance observed in patients poses the biggest challenge. Xenograft models generated by injecting immune-deficient mice with patient-derived human cancer cell lines are practical models to study therapeutics. Despite their ease of use and consistent tumor growth, these models have some important limitations, such as being unable to mount an effective immune response; the inability to represent cancer cell heterogeneity present in human tumors accurately, which is known to impact tumor evolution; and resistance to chemotherapy and subsequent chemotherapy-induced anti-tumor immune response. In this sense, the generation of PDX models overcomes some limitations, as surgically derived human tumor samples are implanted in mice (Hylander et al. 2013). For example, fat pad transplanted breast cancer PDX samples grown in NOD-SCID mice resemble the architecture of the original tumors, promote vascularization, and mimic metastatic behavior observed in patients (DeRose et al. 2011). Successful PDX engraftments have also been described for colorectal, lung, pancreatic, gastric, renal, and prostate cancer (Jung et al. 2018). However, the use of immunedeficient mice hinders their utility for immune-based therapies; also, the cross-talk between tumor and host is limited due to species mismatch (Byrne et al. 2017).
Conclusions related to immune oncology generated using xenograft or PDX models should be restricted to questions related to innate immune responses, and the validation in immune-competent models is needed.

Genetically engineered mouse models (GEMMs) that express known oncogenes or inactivate tumor suppressor genes combined with genetic perturbations in stromal cells have proved to be useful to study tumor immune surveillance in a genetically controlled system. Examples of GEMMs are the MMTV-PyMT breast cancer model and Kras- and Trp53-driven mouse models of lung, pancreatic, and colorectal cancer (Gopinathan et al. 2015; Zitvogel et al. 2016), among others. These models develop spontaneous tumors, metastasis, and immune-sufficient response and display levels of cellular and antigenic heterogeneity. However, they have some limitations, such as the long lead time of generation and poor tropism of metastasis compared with patients (for example, bone and brain metastasis). More recently, the generation of humanized PDX models offers a more sophisticated alternative. In this model, irradiated immune-deficient mice are reconstituted with a human immune system (Rongvaux et al. 2014; Verma et al. 2017)I. As an example, human hepatocellular carcinoma (HCC) PDX tumors implanted in irradiated NOD-SCID II2rg-/- (NSG) mice reconstituted with human $\mathrm{CD}_{3} 4^{+}$hematopoietic stem cells exhibit human leukocytes infiltrated in tumors, phenotypes associated with immune exhaustion, and therapeutic response to pembrolizumab and ipilimumab (Zhao et al. 2018). Although there is no perfect experimental model, the ideal preclinical model to study tumor-associated cancer cells should maintain the cellular and antigenic heterogeneity present in human tumors and mimic not only their innate and adaptive immune surveillance but also the metastatic behavior observed in patients.

Another major challenge is determining whether the current insights into cancer-associated immune response from primary tumors can be used to infer molecular mechanisms that explain the cancer cell-immune cell cross-talk in metastatic tumors. Those cells that successfully reach the post-dissemination phase of the metastatic cascade differ in some respects from their counterparts in primary tumors; for example, cancer cells can acquire mutations and evolve independently (Yates et al. 2017). Also, it is likely that cancer cells that have successfully colonized a distant organ have already been selected as therapy-resistant (Doherty et al. 2016). While it is clear that metastatic cells must develop mechanisms to avoid immune attack in the new colonized organ, little is known about the immune-related mechanisms operating at this level. The lack of reliable preclinical models of spontaneous metastasis leaves current research dependent mainly on the better described lung metastasis models, while other metastases-bone, brain, liver, intestine, and adrenal-remain woefully understudied. Furthermore, depending on the type of metastatic carcinoma and the level of its spread, the current treatments include chemotherapy, hormone therapy, and radiotherapy, leaving surgery as an option for few patients, thus limiting the access to metastatic specimens for further 
characterization. With the advent of new single-cell technologies in transcriptomics and proteomics, future efforts should be focused on understanding the landscapes of immune infiltration in human metastatic tumors, as dissecting the complex interactions between the immune population and disseminated cancer cells could lead to the description of predictive biomarkers to identify dormant micrometastases in patients and, ultimately, the development of new immunotherapies to target metastatic tumors.

\section{Concluding remarks}

Immunological experiments during the last two decades have answered many important questions related to the causal relationship between chronic inflammation and carcinogenesis. Today, oncoimmunology is a field of rapid evolution and maturation. The development of new preclinical models and high-resolution technologies has provided otherwise inaccessible data, opening up exciting new avenues, exemplified by how targeting the immune system to fight cancer is becoming a reality, as evidenced by the relative success of current immunotherapies.

There clearly remains much work to be done, and there are many challenges to face. First, it will be necessary to develop high-fidelity immuno-sufficient preclinical models that incorporate the cellular and antigenic heterogeneity of cancer cells observed in patients. Second, a better understanding of the immune cross-talk that results in tumoricidal immunity will lead to the rational design of targeted therapies that will improve the efficiency of the current immunotherapies. Third, since $>90 \%$ of cancerassociated deaths result from development of metastasis (Jemal et al. 2008; Siegel et al. 2016), we need to verify whether the data generated in primary tumors can be used to infer molecular insights into metastatic tumors. Last, a significant effort into learning more about immune surveillance associated with less-studied metastasic sites, including liver, bone, and brain metastasis, is needed.

\section{Acknowledgments}

We apologize to those scientists whose studies were not cited here owing to space constraints. We thank Isabella Robles for her assistance in writing the manuscript. This study was supported by funds from the National Cancer Institute (R01 CA057621 and U01 CA190851) and the Parker Institute for Cancer Immunotherapy (to Z.W.), a Becas Chile post-doctoral fellowship (to H.G.), and funds from the Tegger Foundation, the Wenner-Gren Foundations, the Sweden-America Foundation, the Swedish Society of Medicine, and the Swedish Society for Medical Research (to C.H.).

\section{References}

Abraham D, Zins K, Sioud M, Lucas T, Schafer R, Stanley ER, Aharinejad S. 2010. Stromal cell-derived CSF-1 blockade prolongs xenograft survival of CSF-1-negative neuroblastoma. Int J Cancer 126: 1339-1352.

Allaoui R, Hagerling C, Desmond E, Warfvinge CF, Jirstrom K, Leandersson K. 2017. Infiltration of $\gamma \delta \mathrm{T}$ cells, $\mathrm{IL}-17^{+} \mathrm{T}$ cells and FoxP3 ${ }^{+} \mathrm{T}$ cells in human breast cancer. Cancer Biomark 20: 395-409.

Andreu P, Johansson M, Affara NI, Pucci F, Tan T, Junankar S, Korets L, Lam J, Tawfik D, DeNardo DG, et al. 2010. FcR $\gamma$ activation regulates inflammation-associated squamous carcinogenesis. Cancer Cell 17: 121-134.

Andrews DM, Sullivan LC, Baschuk N, Chan CJ, Berry R, Cotterell CL, Lin J, Halse H, Watt SV, Poursine-Laurent J, et al. 2012. Recognition of the nonclassical MHC class I molecule H2-M3 by the receptor Ly49A regulates the licensing and activation of NK cells. Nat Immunol 13: 1171-1177.

Askeland EJ, Newton MR, O'Donnell MA, Luo Y. 2012. Bladder cancer immunotherapy: BCG and beyond. Adv Urol 2012: 181987.

Balkwill F, Mantovani A. 2001. Inflammation and cancer: back to Virchow? Lancet 357: 539-545.

Beaugerie L, Svrcek M, Seksik P, Bouvier AM, Simon T, Allez M, Brixi H, Gornet JM, Altwegg R, Beau P, et al. 2013. Risk of colorectal high-grade dysplasia and cancer in a prospective observational cohort of patients with inflammatory bowel disease. Gastroenterology 145: 166-175 e168.

Bedard PL, Hansen AR, Ratain MJ, Siu LL. 2013. Tumour heterogeneity in the clinic. Nature 501: 355-364.

Beer TM, Bernstein GT, Corman JM, Glode LM, Hall SI, Poll WL, Schellhammer PF, Jones LA, Xu Y, Kylstra JW, et al. 2011. Randomized trial of autologous cellular immunotherapy with sipuleucel-T in androgen-dependent prostate cancer. Clin Cancer Res 17: 4558-4567.

Bergers G, Brekken R, McMahon G, Vu TH, Itoh T, Tamaki K, Tanzawa K, Thorpe P, Itohara S, Werb Z, et al. 2000. Matrix metalloproteinase- 9 triggers the angiogenic switch during carcinogenesis. Nat Cell Biol 2: 737-744.

Bidwell BN, Slaney CY, Withana NP, Forster S, Cao Y, Loi S, Andrews D, Mikeska T, Mangan NE, Samarajiwa SA, et al. 2012. Silencing of Irf7 pathways in breast cancer cells promotes bone metastasis through immune escape. Nat Med 18: $1224-1231$.

Bix M, Liao NS, Zijlstra M, Loring J, Jaenisch R, Raulet D. 1991. Rejection of class I MHC-deficient haemopoietic cells by irradiated MHC-matched mice. Nature 349: 329-331.

Boger C, Behrens HM, Kruger S, Rocken C. 2017. The novel negative checkpoint regulator VISTA is expressed in gastric carcinoma and associated with PD-L1/PD-1: a future perspective for a combined gastric cancer therapy? Oncoimmunology 6: e1293215.

Bonapace L, Coissieux MM, Wyckoff J, Mertz KD, Varga Z, Junt T, Bentires-Alj M. 2014. Cessation of CCL2 inhibition accelerates breast cancer metastasis by promoting angiogenesis. Nature 515: 130-133.

Bos PD, Plitas G, Rudra D, Lee SY, Rudensky AY. 2013. Transient regulatory $\mathrm{T}$ cell ablation deters oncogene-driven breast cancer and enhances radiotherapy. J Exp Med 210: 2435-2466.

Bosch FX, Lorincz A, Munoz N, Meijer CJ, Shah KV. 2002. The causal relation between human papillomavirus and cervical cancer. J Clin Pathol 55: 244-265.

Bottcher JP, Bonavita E, Chakravarty P, Blees H, Cabeza-Cabrerizo M, Sammicheli S, Rogers NC, Sahai E, Zelenay S, Reis ESC. 2018. NK cells stimulate recruitment of cDC1 into the tumor microenvironment promoting cancer immune control. Cell 172: 1022-1037.e14.

Bouwhuis MG, Gast A, Figl A, Eggermont AM, Hemminki K, Schadendorf D, Kumar R. 2010. Polymorphisms in the CD28/CTLA4/ICOS genes: role in malignant melanoma susceptibility and prognosis? Cancer Immunol Immunother 59: 303-312. 
Broz ML, Binnewies M, Boldajipour B, Nelson AE, Pollack JL, Erle DJ, Barczak A, Rosenblum MD, Daud A, Barber DL, et al. 2014. Dissecting the tumor myeloid compartment reveals rare activating antigen-presenting cells critical for $\mathrm{T}$ cell immunity. Cancer Cell 26: 938.

Byrne AT, Alferez DG, Amant F, Annibali D, Arribas J, Biankin AV, Bruna A, Budinska E, Caldas C, Chang DK, et al. 2017. Interrogating open issues in cancer precision medicine with patient-derived xenografts. Nat Rev Cancer 17: 254-268.

Campbell DJ. 2015. Control of regulatory $\mathrm{T}$ cell migration, function, and homeostasis. Eur I Immunol 195: 2507-2513.

Casbon AJ, Lohela M, Werb Z. 2015. Delineating CSF-1dependent regulation of myeloid cell diversity in tumors. Oncoimmunology 4: e1008871.

Cerwenka A, Lanier LL. 2016. Natural killer cell memory in infection, inflammation and cancer. Nat Rev Immunol 16: 112-123.

Cerwenka A, Bakker AB, McClanahan T, Wagner J, Wu J, Phillips JH, Lanier LL. 2000. Retinoic acid early inducible genes define a ligand family for the activating NKG2D receptor in mice. Immunity 12: 721-727.

Chambers AF, Werb Z. 2015. Invasion and metastasis-recent advances and future challenges. J Mol Med (Berl) 93: 361-368.

Chang SH, Mirabolfathinejad SG, Katta H, Cumpian AM, Gong L, Caetano MS, Moghaddam SJ, Dong C. 2014. T helper 17 cells play a critical pathogenic role in lung cancer. Proc Natl Acad Sci 111: 5664-5669.

Chen Q, Ross AC. 2012. All-trans-retinoic acid and the glycolipid a-galactosylceramide combined reduce breast tumor growth and lung metastasis in a 4T1 murine breast tumor model. Nutr Cancer 64: 1219-1227.

Chiba S, Ikushima H, Ueki H, Yanai H, Kimura Y, Hangai S, Nishio J, Negishi H, Tamura T, Saijo S, et al. 2014. Recognition of tumor cells by Dectin-1 orchestrates innate immune cells for anti-tumor responses. eLife 3: e04177.

Chin Y, Janseens J, Vandepitte J, Vandenbrande J, Opdebeek L, Raus J. 1992. Phenotypic analysis of tumor-infiltrating lymphocytes from human breast cancer. Anticancer Res 12: 1463-1466.

Chong TW, Goh FY, Sim MY, Huang HH, Thike AA, Lim WK, Teh BT, Tan PH. 2015. CD1d expression in renal cell carcino$\mathrm{ma}$ is associated with higher relapse rates, poorer cancerspecific and overall survival. J Clin Pathol 68: 200-205.

Chowell D, Morris LGT, Grigg CM, Weber JK, Samstein RM, Makarov V, Kuo F, Kendall SM, Requena D, Riaz N, et al. 2018. Patient HLA class I genotype influences cancer response to checkpoint blockade immunotherapy. Science 359: 582-587.

Clemente CG, Mihm MC Jr, Bufalino R, Zurrida S, Collini P, Cascinelli N. 1996. Prognostic value of tumor infiltrating lymphocytes in the vertical growth phase of primary cutaneous melanoma. Cancer 77: 1303-1310.

Coca S, Perez-Piqueras J, Martinez D, Colmenarejo A, Saez MA, Vallejo C, Martos JA, Moreno M. 1997. The prognostic significance of intratumoral natural killer cells in patients with colorectal carcinoma. Cancer 79: 2320-2328.

Coffelt SB, Kersten K, Doornebal CW, Weiden J, Vrijland K, Hau CS, Verstegen NJM, Ciampricotti M, Hawinkels L, Jonkers J, et al. 2015. IL-17-producing $\gamma \delta \mathrm{T}$ cells and neutrophils conspire to promote breast cancer metastasis. Nature 522: 345-348.

Colonna M, Spies T, Strominger JL, Ciccone E, Moretta A, Moretta L, Pende D, Viale O. 1992. Alloantigen recognition by two human natural killer cell clones is associated with HLA-C or a closely linked gene. Proc Natl Acad Sci 89: 7983-7985.
Cools-Lartigue J, Spicer J, McDonald B, Gowing S, Chow S, Giannias B, Bourdeau F, Kubes P, Ferri L. 2013. Neutrophil extracellular traps sequester circulating tumor cells and promote metastasis. J Clin Invest 123: 3446-3458.

Cools-Lartigue J, Spicer J, Najmeh S, Ferri L. 2014. Neutrophil extracellular traps in cancer progression. Cell Mol Life Sci 71: 4179-4194.

Costa-Silva B, Aiello NM, Ocean AJ, Singh S, Zhang H, Thakur BK, Becker A, Hoshino A, Mark MT, Molina H, et al. 2015. Pancreatic cancer exosomes initiate pre-metastatic niche formation in the liver. Nat Cell Biol 17: 816-826.

Coussens LM, Werb Z. 2002. Inflammation and cancer. Nature 420: $860-867$.

DeNardo DG, Brennan DJ, Rexhepaj E, Ruffell B, Shiao SL, Madden SF, Gallagher WM, Wadhwani N, Keil SD, Junaid SA, et al. 2011. Leukocyte complexity predicts breast cancer survival and functionally regulates response to chemotherapy. Cancer Discov 1: 54-67.

DeRose YS, Wang G, Lin YC, Bernard PS, Buys SS, Ebbert MT, Factor R, Matsen C, Milash BA, Nelson E, et al. 2011. Tumor grafts derived from women with breast cancer authentically reflect tumor pathology, growth, metastasis and disease outcomes. Nat Med 17: 1514-1520.

De Silva NS, Klein U. 2015. Dynamics of B cells in germinal centres. Nat Rev Immunol 15: 137-148.

de Visser KE, Korets LV, Coussens LM. 2005. De novo carcinogenesis promoted by chronic inflammation is B lymphocyte dependent. Cancer Cell 7: 411-423.

Diamond MS, Kinder M, Matsushita H, Mashayekhi M, Dunn GP, Archambault JM, Lee H, Arthur CD, White JM, Kalinke $\mathrm{U}$, et al. 2011. Type I interferon is selectively required by dendritic cells for immune rejection of tumors. I Exp Med 208: 1989-2003.

Diefenbach A, Jamieson AM, Liu SD, Shastri N, Raulet DH. 2000. Ligands for the murine NKG2D receptor: expression by tumor cells and activation of NK cells and macrophages. Nat Immunol 1: 119-126.

Diefenbach A, Jensen ER, Jamieson AM, Raulet DH. 2001. Rae1 and H60 ligands of the NKG2D receptor stimulate tumour immunity. Nature 413: 165-171.

Dieu-Nosjean MC, Antoine M, Danel C, Heudes D, Wislez M, Poulot V, Rabbe N, Laurans L, Tartour E, de Chaisemartin L, et al. 2008. Long-term survival for patients with nonsmall-cell lung cancer with intratumoral lymphoid structures. J Clin Oncol 26: 4410-4417.

Di Giacomo AM, Ascierto PA, Pilla L, Santinami M, Ferrucci PF, Giannarelli D, Marasco A, Rivoltini L, Simeone E, Nicoletti SV, et al. 2012. Ipilimumab and fotemustine in patients with advanced melanoma (NIBIT-M1): an open-label, single-arm phase 2 trial. Lancet Oncol 13: 879-886.

Di Giacomo AM, Valente M, Covre A, Danielli R, Maio M. 2017. Immunotherapy targeting immune check-point(s) in brain metastases. Cytokine Growth Factor Rev 36: 33-38.

Dilmec F, Ozgonul A, Uzunkoy A, Akkafa F. 2008. Investigation of CTLA-4 and CD28 gene polymorphisms in a group of Turkish patients with colorectal cancer. Int I Immunogenet 35: 317-321.

Doherty MR, Smigiel JM, Junk DJ, Jackson MW. 2016. Cancer stem cell plasticity drives therapeutic resistance. Cancers 8: $\mathrm{E} 8$.

Dominguez-Soto A, Sierra-Filardi E, Puig-Kroger A, Perez-Maceda B, Gomez-Aguado F, Corcuera MT, Sanchez-Mateos P, Corbi AL. 2011. Dendritic cell-specific ICAM-3-grabbing nonintegrin expression on M2-polarized and tumor-associated 
macrophages is macrophage-CSF dependent and enhanced by tumor-derived IL-6 and IL-10. I Immunol 186: 2192-2200.

Donadon M, Hudspeth K, Cimino M, Di Tommaso L, Preti M, Tentorio P, Roncalli M, Mavilio D, Torzilli G. 2017. Increased infiltration of natural killer and T cells in colorectal liver metastases improves patient overall survival. J Gastrointest Surg 21: $1226-1236$.

Donskov F. 2013. Immunomonitoring and prognostic relevance of neutrophils in clinical trials. Semin Cancer Biol 23: 200-207.

Erfani N, Razmkhah M, Talei AR, Pezeshki AM, Doroudchi M, Monabati A, Ghaderi A. 2006. Cytotoxic T lymphocyte antigen-4 promoter variants in breast cancer. Cancer Genet Cytogenet 165: 114-120.

Erfani N, Mehrabadi SM, Ghayumi MA, Haghshenas MR, Mojtahedi Z, Ghaderi A, Amani D. 2012. Increase of regulatory $T$ cells in metastatic stage and CTLA- 4 over expression in lymphocytes of patients with non-small cell lung cancer (NSCLC). Lung Cancer 77: 306-311.

Espinosa V, Jhingran A, Dutta O, Kasahara S, Donnelly R, Du P, Rosenfeld J, Leiner I, Chen CC, Ron Y, et al. 2014. Inflammatory monocytes orchestrate innate antifungal immunity in the lung. PLOS Pathog 10: e1003940.

Ferlay J, Soerjomataram I, Dikshit R, Eser S, Mathers C, Rebelo M, Parkin DM, Forman D, Bray F. 2015. Cancer incidence and mortality worldwide: sources, methods and major patterns in GLOBOCAN 2012. Int I Cancer 136: E359-E386.

Finisguerra V, Di Conza G, Di Matteo M, Serneels J, Costa S, Thompson AA, Wauters E, Walmsley S, Prenen H, Granot $\mathrm{Z}$, et al. 2015. MET is required for the recruitment of antitumoural neutrophils. Nature 522: 349-353.

Francisco LM, Salinas VH, Brown KE, Vanguri VK, Freeman GJ, Kuchroo VK, Sharpe AH. 2009. PD-L1 regulates the development, maintenance, and function of induced regulatory T cells. I Exp Med 206: 3015-3029.

Fridlender ZG, Sun J, Kim S, Kapoor V, Cheng G, Ling L, Worthen GS, Albelda SM. 2009. Polarization of tumor-associated neutrophil phenotype by TGF- $\beta$ : 'N1' versus 'N2' TAN. Cancer Cell 16: 183-194.

Fridman WH, Pages F, Sautes-Fridman C, Galon J. 2012. The immune contexture in human tumours: impact on clinical outcome. Nat Rev Cancer 12: 298-306.

Frisch M, Biggar RJ, Engels EA, Goedert JJ, Group AI-CMRS. 2001. Association of cancer with AIDS-related immunosuppression in adults. JAMA 285: 1736-1745.

Frydrychowicz M, Boruczkowski M, Kolecka-Bednarczyk A, Dworacki G. 2017. The dual role of treg in cancer. Scand $J$ Immunol 86: 436-443.

Furudate S, Fujimura T, Kambayashi Y, Hidaka T, Hashimoto A, Aiba S. 2016. Sequential therapy with nivolumab followed by ipilimumab induces complete response in metastatic melanoma of the lung but with severe hepatotoxicities. Case Rep Oncol 9: 644-649.

Gabrilovich DI. 2017. Myeloid-derived suppressor cells. Cancer Immunol Res 5: 3-8.

Gabrilovich DI, Chen HL, Girgis KR, Cunningham HT, Meny GM, Nadaf S, Kavanaugh D, Carbone DP. 1996. Production of vascular endothelial growth factor by human tumors inhibits the functional maturation of dendritic cells. Nat Med 2: 1096-1103.

Gasser S, Orsulic S, Brown EJ, Raulet DH. 2005. The DNA damage pathway regulates innate immune system ligands of the NKG2D receptor. Nature 436: 1186-1190.

Gebremeskel S, Clattenburg DR, Slauenwhite D, Lobert L, Johnston B. 2015. Natural killer T cell activation overcomes im- munosuppression to enhance clearance of postsurgical breast cancer metastasis in mice. Oncoimmunology 4: e995562.

Germano G, Lamba S, Rospo G, Barault L, Magri A, Maione F, Russo M, Crisafulli G, Bartolini A, Lerda G, et al. 2017. Inactivation of DNA repair triggers neoantigen generation and impairs tumour growth. Nature 552: 116-120.

Glasner A, Ghadially H, Gur C, Stanietsky N, Tsukerman P, Enk J, Mandelboim O. 2012. Recognition and prevention of tumor metastasis by the NK receptor NKp46/NCR1. J Immunol 188: 2509-2515.

Goldberg SB, Gettinger SN, Mahajan A, Chiang AC, Herbst RS, Sznol M, Tsiouris AJ, Cohen J, Vortmeyer A, Jilaveanu L, et al. 2016. Pembrolizumab for patients with melanoma or non-small-cell lung cancer and untreated brain metastases: early analysis of a non-randomised, open-label, phase 2 trial. Lancet Oncol 17: 976-983.

Gong L, Cumpian AM, Caetano MS, Ochoa CE, De la Garza MM, Lapid DJ, Mirabolfathinejad SG, Dickey BF, Zhou Q, Moghaddam SJ. 2013. Promoting effect of neutrophils on lung tumorigenesis is mediated by CXCR2 and neutrophil elastase. Mol Cancer 12: 154.

Gonzalez H, Robles I, Werb Z. 2018. Innate and acquired immune surveillance in the postdissemination phase of metastasis. FEBS J 285: 654-664.

Gopinathan A, Morton JP, Jodrell DI, Sansom OJ. 2015. GEMMs as preclinical models for testing pancreatic cancer therapies. Dis Model Mech 8: 1185-1200.

Gotwals P, Cameron S, Cipolletta D, Cremasco V, Crystal A, Hewes B, Mueller B, Quaratino S, Sabatos-Peyton C, Petruzzelli L, et al. 2017. Prospects for combining targeted and conventional cancer therapy with immunotherapy. Nat Rev Cancer 17: 286-301.

Governa V, Trella E, Mele V, Tornillo L, Amicarella F, Cremonesi E, Muraro MG, Xu H, Droeser R, Daster SR, et al. 2017. The interplay between neutrophils and $\mathrm{CD}^{+} \mathrm{T}$ cells improves survival in human colorectal cancer. Clin Cancer Res 23: 3847-3858.

Granot Z, Henke E, Comen EA, King TA, Norton L, Benezra R. 2011. Tumor entrained neutrophils inhibit seeding in the premetastatic lung. Cancer Cell 20: 300-314.

Grivennikov SI, Greten FR, Karin M. 2010. Immunity, inflammation, and cancer. Cell 140: 883-899.

Guerra N, Tan YX, Joncker NT, Choy A, Gallardo F, Xiong N, Knoblaugh S, Cado D, Greenberg NM, Raulet DH. 2008. NKG2D-deficient mice are defective in tumor surveillance in models of spontaneous malignancy. Immunity 28: 571-580.

Guerriero JL, Sotayo A, Ponichtera HE, Castrillon JA, Pourzia AL, Schad S, Johnson SF, Carrasco RD, Lazo S, Bronson RT, et al. 2017. Class IIa HDAC inhibition reduces breast tumours and metastases through anti-tumour macrophages. Nature 543: 428-432.

Gupta GP, Massague J. 2006. Cancer metastasis: building a framework. Cell 127: 679-695.

Gupta SC, Kim JH, Prasad S, Aggarwal BB. 2010. Regulation of survival, proliferation, invasion, angiogenesis, and metastasis of tumor cells through modulation of inflammatory pathways by nutraceuticals. Cancer Metastasis Rev 29: 405-434.

Hadinia A, Hossieni SV, Erfani N, Saberi-Firozi M, Fattahi MJ, Ghaderi A. 2007. CTLA-4 gene promoter and exon 1 polymorphisms in Iranian patients with gastric and colorectal cancers. J Gastroenterol Hepatol 22: 2283-2287.

Halama N, Michel S, Kloor M, Zoernig I, Benner A, Spille A, Pommerencke T, von Knebel DM, Folprecht G, Luber B, et al. 2011. Localization and density of immune cells in the invasive margin of human colorectal cancer liver metastases 
are prognostic for response to chemotherapy. Cancer Res 71: 5670-5677.

Halama N, Zoernig I, Berthel A, Kahlert C, Klupp F, Suarez-Carmona M, Suetterlin T, Brand K, Krauss J, Lasitschka F, et al. 2016. Tumoral immune cell exploitation in colorectal cancer metastases can be targeted effectively by anti-CCR 5 therapy in cancer patients. Cancer Cell 29: 587-601.

Hamid O, Robert C, Daud A, Hodi FS, Hwu WJ, Kefford R, Wolchok JD, Hersey P, Joseph RW, Weber JS, et al. 2013. Safety and tumor responses with lambrolizumab (anti-PD-1) in melanoma. N Engl J Med 369: 134-144.

Hanahan D, Weinberg RA. 2011. Hallmarks of cancer: the next generation. Cell 144: 646-674.

Hanna RN, Cekic C, Sag D, Tacke R, Thomas GD, Nowyhed H, Herrley E, Rasquinha N, McArdle S, Wu R, et al. 2015. Patrolling monocytes control tumor metastasis to the lung. Science 350: $985-990$.

Hanson HL, Donermeyer DL, Ikeda H, White JM, Shankaran V, Old LJ, Shiku H, Schreiber RD, Allen PM. 2000. Eradication of established tumors by $\mathrm{CD}^{+} \mathrm{T}$ cell adoptive immunotherapy. Immunity 13: 265-276.

Headley MB, Bins A, Nip A, Roberts EW, Looney MR, Gerard A, Krummel MF. 2016. Visualization of immediate immune responses to pioneer metastatic cells in the lung. Nature 531: 513-517.

Herbst RS, Soria JC, Kowanetz M, Fine GD, Hamid O, Gordon MS, Sosman JA, McDermott DF, Powderly JD, Gettinger $\mathrm{SN}$, et al. 2014. Predictive correlates of response to the antiPD-L1 antibody MPDL3280A in cancer patients. Nature 515: 563-567.

Hildner K, Edelson BT, Purtha WE, Diamond M, Matsushita H, Kohyama M, Calderon B, Schraml BU, Unanue ER, Diamond MS, et al. 2008. Batf3 deficiency reveals a critical role for $\mathrm{CD} \mathrm{a}^{+}$dendritic cells in cytotoxic T cell immunity. Science 322: 1097-1100.

Hix LM, Shi YH, Brutkiewicz RR, Stein PL, Wang CR, Zhang M. 2011. CD1d-expressing breast cancer cells modulate NKT cell-mediated antitumor immunity in a murine model of breast cancer metastasis. PLoS One 6: e20702.

Hosseini H, Obradovic MM, Hoffmann M, Harper KL, Sosa MS, Werner-Klein M, Nanduri LK, Werno C, Ehrl C, Maneck M, et al. 2016. Early dissemination seeds metastasis in breast cancer. Nature 540: 552-558.

Houghton AM, Rzymkiewicz DM, Ji H, Gregory AD, Egea EE, Metz HE, Stolz DB, Land SR, Marconcini LA, Kliment CR, et al. 2010. Neutrophil elastase-mediated degradation of IRS1 accelerates lung tumor growth. Nat Med 16: 219-223.

Howe LR, Subbaramaiah K, Hudis CA, Dannenberg AJ. 2013. Molecular pathways: adipose inflammation as a mediator of obesity-associated cancer. Clin Cancer Res 19: 6074-6083.

Huang S, Van Arsdall M, Tedjarati S, McCarty M, Wu W, Langley R, Fidler IJ. 2002. Contributions of stromal metalloproteinase9 to angiogenesis and growth of human ovarian carcinoma in mice. J Natl Cancer Inst 94: 1134-1142.

Hussain SP, Amstad P, Raja K, Ambs S, Nagashima M, Bennett WP, Shields PG, Ham AJ, Swenberg JA, Marrogi AJ, et al. 2000. Increased p53 mutation load in noncancerous colon tissue from ulcerative colitis: a cancer-prone chronic inflammatory disease. Cancer Res 60: 3333-3337.

Hylander BL, Punt N, Tang H, Hillman J, Vaughan M, Bshara W, Pitoniak R, Repasky EA. 2013. Origin of the vasculature supporting growth of primary patient tumor xenografts. J Transl Med 11: 110.

Iannello A, Thompson TW, Ardolino M, Lowe SW, Raulet DH. 2013. p53-dependent chemokine production by senescent tumor cells supports NKG2D-dependent tumor elimination by natural killer cells. J Exp Med 210: 2057-2069.

Iannello A, Thompson TW, Ardolino M, Marcus A, Raulet DH. 2016. Immunosurveillance and immunotherapy of tumors by innate immune cells. Curr Opin Immunol 38: 52-58.

Ishigami S, Natsugoe S, Tokuda K, Nakajo A, Che X, Iwashige H, Aridome K, Hokita S, Aikou T. 2000. Prognostic value of intratumoral natural killer cells in gastric carcinoma. Cancer 88: 577-583.

Jamieson T, Clarke M, Steele CW, Samuel MS, Neumann J, Jung A, Huels D, Olson MF, Das S, Nibbs RJ, et al. 2012. Inhibition of CXCR2 profoundly suppresses inflammation-driven and spontaneous tumorigenesis. J Clin Invest 122: 3127-3144.

Jemal A, Siegel R, Ward E, Hao Y, Xu J, Murray T, Thun MJ. 2008. Cancer statistics, 2008. CA Cancer J Clin 58: 71-96.

Jimenez-Sanchez A, Memon D, Pourpe S, Veeraraghavan H, Li Y, Vargas HA, Gill MB, Park KJ, Zivanovic O, Konner J, et al. 2017. Heterogeneous tumor-immune microenvironments among differentially growing metastases in an ovarian cancer patient. Cell 170: 927-938.e20.

Joshi NS, Akama-Garren EH, Lu Y, Lee DY, Chang GP, Li A, DuPage M, Tammela T, Kerper NR, Farago AF, et al. 2015. Regulatory $\mathrm{T}$ cells in tumor-associated tertiary lymphoid structures suppress anti-tumor $\mathrm{T}$ cell responses. Immunity 43: $579-590$.

Jung J, Seol HS, Chang S. 2018. The generation and application of patient-derived xenograft model for cancer research. Cancer Res Treat 50: 1-10.

Kalams SA, Walker BD. 1998. The critical need for CD4 help in maintaining effective cytotoxic $\mathrm{T}$ lymphocyte responses. J Exp Med 188: 2199-2204.

Karlhofer FM, Ribaudo RK, Yokoyama WM. 1992. MHC class I alloantigen specificity of Ly-49+ IL-2-activated natural killer cells. Nature 358: 66-70.

Katoh H, Wang D, Daikoku T, Sun H, Dey SK, Dubois RN. 2013. CXCR2-expressing myeloid-derived suppressor cells are essential to promote colitis-associated tumorigenesis. Cancer Cell 24: 631-644.

Keizman D, Ish-Shalom M, Huang P, Eisenberger MA, Pili R, Hammers H, Carducci MA. 2012. The association of pre-treatment neutrophil to lymphocyte ratio with response rate, progression free survival and overall survival of patients treated with sunitinib for metastatic renal cell carcinoma. Eur $J$ Cancer 48: 202-208.

Kessenbrock K, Plaks V, Werb Z. 2010. Matrix metalloproteinases: regulators of the tumor microenvironment. Cell 141: 52-67.

Khaghanzadeh N, Erfani N, Ghayumi MA, Ghaderi A. 2010. CTLA4 gene variations and haplotypes in patients with lung cancer. Cancer Genet Cytogenet 196: 171-174.

Kirilovsky A, Marliot F, El Sissy C, Haicheur N, Galon J, Pages F. 2016. Rational bases for the use of the Immunoscore in routine clinical settings as a prognostic and predictive biomarker in cancer patients. Int Immunol 28: 373-382.

Kitamura T, Qian BZ, Pollard JW. 2015. Immune cell promotion of metastasis. Nat Rev Immunol 15: 73-86.

Kolaczkowska E, Kubes P. 2013. Neutrophil recruitment and function in health and inflammation. Nat Rev Immunol 13: 159-175.

Kondo T, Nakazawa H, Ito F, Hashimoto Y, Osaka Y, Futatsuyama K, Toma H, Tanabe K. 2006. Favorable prognosis of renal cell carcinoma with increased expression of chemokines associated with a Th1-type immune response. Cancer Sci 97: 780-786. 
Kreso A, Dick JE. 2014. Evolution of the cancer stem cell model. Cell Stem Cell 14: 275-291.

Kumar V, Patel S, Tcyganov E, Gabrilovich DI. 2016. The nature of myeloid-derived suppressor cells in the tumor microenvironment. Trends Immunol 37: 208-220.

Kusuda T, Shigemasa K, Arihiro K, Fujii T, Nagai N, Ohama K. 2005. Relative expression levels of Th1 and Th2 cytokine mRNA are independent prognostic factors in patients with ovarian cancer. Oncol Rep 13: 1153-1158.

Lakatos PL, Lakatos L. 2008. Risk for colorectal cancer in ulcerative colitis: changes, causes and management strategies. World J Gastroenterol 14: 3937-3947.

Lambert AW, Pattabiraman DR, Weinberg RA. 2017. Emerging biological principles of metastasis. Cell 168: 670-691.

Lanier LL. 2005. Missing self, NK cells, and The White Album. J Immunol 174: 6565.

Lavin Y, Mortha A, Rahman A, Merad M. 2015. Regulation of macrophage development and function in peripheral tissues. Nat Rev Immunol 15: 731-744.

Lavin Y, Kobayashi S, Leader A, Amir ED, Elefant N, Bigenwald C, Remark R, Sweeney R, Becker CD, Levine JH, et al. 2017. Innate immune landscape in early lung adenocarcinoma by paired single-cell analyses. Cell 169: 750-765.e17.

Lee YJ, Wang H, Starrett GJ, Phuong V, Jameson SC, Hogquist KA. 2015. Tissue-specific distribution of iNKT cells impacts their cytokine response. Immunity 43: 566-578.

Liao NS, Bix M, Zijlstra M, Jaenisch R, Raulet D. 1991. MHC class I deficiency: susceptibility to natural killer (NK) cells and impaired NK activity. Science 253: 199-202.

Liu RB, Engels B, Arina A, Schreiber K, Hyjek E, Schietinger A, Binder DC, Butz E, Krausz T, Rowley DA, et al. 2012a. Densely granulated murine NK cells eradicate large solid tumors. Cancer Res 72: 1964-1974.

Liu XV, Ho SS, Tan JJ, Kamran N, Gasser S. 2012b. Ras activation induces expression of Raetl family NK receptor ligands. I Immunol 189: 1826-1834.

Long KB, Gladney WL, Tooker GM, Graham K, Fraietta JA, Beatty GL. 2016. IFN $\gamma$ and CCL2 cooperate to redirect tumor-infiltrating monocytes to degrade fibrosis and enhance chemotherapy efficacy in pancreatic carcinoma. Cancer Discov 6: 400-413.

Lu X, Kang Y. 2009. Chemokine (C-C motif) ligand 2 engages $\mathrm{CCR}^{+}$stromal cells of monocytic origin to promote breast cancer metastasis to lung and bone. J Biol Chem 284: 29087-29096.

Ma Y, Adjemian S, Mattarollo SR, Yamazaki T, Aymeric L, Yang H, Portela Catani JP, Hannani D, Duret H, Steegh K, et al. 2013. Anticancer chemotherapy-induced intratumoral recruitment and differentiation of antigen-presenting cells. Immunity 38: 729-741.

Malladi S, Macalinao DG, Jin X, He L, Basnet H, Zou Y, de Stanchina E, Massague J. 2016. Metastatic latency and immune evasion through autocrine inhibition of WNT. Cell 165: 45-60.

Manome Y, Wen PY, Hershowitz A, Tanaka T, Rollins BJ, Kufe DW, Fine HA. 1995. Monocyte chemoattractant protein-1 (MCP-1) gene transduction: an effective tumor vaccine strategy for non-intracranial tumors. Cancer Immunol Immunother 41: 227-235.

Mantovani A, Sozzani S, Locati M, Allavena P, Sica A. 2002. Macrophage polarization: tumor-associated macrophages as a paradigm for polarized M2 mononuclear phagocytes. Trends Immunol 23: 549-555.
Mantovani A, Marchesi F, Malesci A, Laghi L, Allavena P. 2017. Tumour-associated macrophages as treatment targets in oncology. Nat Rev Clin Oncol 14: 399-416.

Marcus A, Gowen BG, Thompson TW, Iannello A, Ardolino M, Deng W, Wang L, Shifrin N, Raulet DH. 2014. Recognition of tumors by the innate immune system and natural killer cells. Adv Immunol 122: 91-128.

Mariathasan S, Turley SJ, Nickles D, Castiglioni A, Yuen K, Wang Y, Kadel Iii EE, Koeppen H, Astarita JL, Cubas R, et al. 2018. TGF $\beta$ attenuates tumour response to PD-L1 blockade by contributing to exclusion of T cells. Nature 554: 544-548.

Marigo I, Bosio E, Solito S, Mesa C, Fernandez A, Dolcetti L, Ugel S, Sonda N, Bicciato S, Falisi E, et al. 2010. Tumor-induced tolerance and immune suppression depend on the C/EBP $\beta$ transcription factor. Immunity 32: 790-802.

Massague J. 2008. TGF $\beta$ in cancer. Cell 134: 215-230.

Matsushita H, Vesely MD, Koboldt DC, Rickert CG, Uppaluri R, Magrini VJ, Arthur CD, White JM, Chen YS, Shea LK, et al. 2012. Cancer exome analysis reveals a T-cell-dependent mechanism of cancer immunoediting. Nature 482: 400-404.

Mazzieri R, Pucci F, Moi D, Zonari E, Ranghetti A, Berti A, Politi LS, Gentner B, Brown JL, Naldini L, et al. 2011. Targeting the ANG2/TIE2 axis inhibits tumor growth and metastasis by impairing angiogenesis and disabling rebounds of proangiogenic myeloid cells. Cancer Cell 19: 512-526.

McGranahan N, Swanton C. 2015. Biological and therapeutic impact of intratumor heterogeneity in cancer evolution. Cancer Cell 27: 15-26.

McGranahan N, Furness AJ, Rosenthal R, Ramskov S, Lyngaa R, Saini SK, Jamal-Hanjani M, Wilson GA, Birkbak NJ, Hiley CT, et al. 2016. Clonal neoantigens elicit $\mathrm{T}$ cell immunoreactivity and sensitivity to immune checkpoint blockade. Science 351: 1463-1469.

McGranahan N, Rosenthal R, Hiley CT, Rowan AJ, Watkins TBK, Wilson GA, Birkbak NJ, Veeriah S, Van Loo P, Herrero J, et al. 2017. Allele-specific HLA loss and immune escape in lung cancer evolution. Cell 171: 1259-1271 e1211.

McIntire RH, Morales PJ, Petroff MG, Colonna M, Hunt JS. 2004. Recombinant HLA-G5 and -G6 drive U937 myelomonocytic cell production of TGF- $\beta 1$. J Leukoc Biol 76: 1220-1228.

Mego M, Gao H, Cohen EN, Anfossi S, Giordano A, Sanda T, Fouad TM, De Giorgi U, Giuliano M, Woodward WA, et al. 2016. Circulating tumor cells (CTC) are associated with defects in adaptive immunity in patients with inflammatory breast cancer. J Cancer 7: 1095-1104.

Metelli A, Wu BX, Fugle CW, Rachidi S, Sun S, Zhang Y, Wu J, Tomlinson S, Howe PH, Yang Y, et al. 2016. Surface expression of TGF $\beta$ docking receptor GARP promotes oncogenesis and immune tolerance in breast cancer. Cancer Res 76: 7106-7117.

Mildner A, Jung S. 2014. Development and function of dendritic cell subsets. Immunity 40: 642-656.

Moretta A, Marcenaro E, Sivori S, Della Chiesa M, Vitale M, Moretta L. 2005. Early liaisons between cells of the innate immune system in inflamed peripheral tissues. Trends Immunol 26: 668-675.

Motohashi S, Nagato K, Kunii N, Yamamoto H, Yamasaki K, Okita K, Hanaoka H, Shimizu N, Suzuki M, Yoshino I, et al. 2009. A phase I-II study of a-galactosylceramide-pulsed IL-2/ GM-CSF-cultured peripheral blood mononuclear cells in patients with advanced and recurrent non-small cell lung cancer. I Immunol 182: 2492-2501.

Motzer RJ, Escudier B, McDermott DF, George S, Hammers HJ, Srinivas S, Tykodi SS, Sosman JA, Procopio G, Plimack ER, 
et al. 2015. Nivolumab versus everolimus in advanced renalcell carcinoma. N Engl J Med 373: 1803-1813.

Moynihan KD, Opel CF, Szeto GL, Tzeng A, Zhu EF, Engreitz JM, Williams RT, Rakhra K, Zhang MH, Rothschilds AM, et al. 2016. Eradication of large established tumors in mice by combination immunotherapy that engages innate and adaptive immune responses. Nat Med 22: 1402-1410.

Mukherii B, Chakraborty NG, Yamasaki S, Okino T, Yamase H, Sporn JR, Kurtzman SK, Ergin MT, Ozols J, Meehan J, et al. 1995. Induction of antigen-specific cytolytic T cells in situ in human melanoma by immunization with synthetic peptide-pulsed autologous antigen presenting cells. Proc Natl Acad Sci 92: 8078-8082.

Nakatsumi H, Matsumoto M, Nakayama KI. 2017. Noncanonical pathway for regulation of CCL2 expression by an mTORC1FOXK1 axis promotes recruitment of tumor-associated macrophages. Cell Rep 21: 2471-2486.

Nestle FO, Alijagic S, Gilliet M, Sun Y, Grabbe S, Dummer R, Burg G, Schadendorf D. 1998. Vaccination of melanoma patients with peptide- or tumor lysate-pulsed dendritic cells. Nat Med 4: 328-332.

Ng TH, Britton GJ, Hill EV, Verhagen J, Burton BR, Wraith DC. 2013. Regulation of adaptive immunity; the role of interleukin-10. Front Immunol 4: 129.

Noy R, Pollard JW. 2014. Tumor-associated macrophages: from mechanisms to therapy. Immunity 41: 49-61.

Oldford SA, Robb JD, Codner D, Gadag V, Watson PH, Drover S. 2006. Tumor cell expression of HLA-DM associates with a Th1 profile and predicts improved survival in breast carcinoma patients. Int Immunol 18: 1591-1602.

Olkhanud PB, Damdinsuren B, Bodogai M, Gress RE, Sen R, Wejksza K, Malchinkhuu E, Wersto RP, Biragyn A. 2011. Tumor-evoked regulatory $\mathrm{B}$ cells promote breast cancer metastasis by converting resting $\mathrm{CD} 4^{+} \mathrm{T}$ cells to T-regulatory cells. Cancer Res 71: 3505-3515.

O'Sullivan C, Lewis CE, Harris AL, McGee JO. 1993. Secretion of epidermal growth factor by macrophages associated with breast carcinoma. Lancet 342: 148-149.

O'Sullivan T, Saddawi-Konefka R, Vermi W, Koebel CM, Arthur C, White JM, Uppaluri R, Andrews DM, Ngiow SF, Teng MW, et al. 2012. Cancer immunoediting by the innate immune system in the absence of adaptive immunity. I Exp Med 209: 1869-1882.

Pai-Scherf L, Blumenthal GM, Li H, Subramaniam S, MishraKalyani PS, He K, Zhao H, Yu J, Paciga M, Goldberg KB, et al. 2017. FDA approval summary: pembrolizumab for treatment of metastatic non-small cell lung cancer: first-line therapy and beyond. Oncologist 22: 1392-1399.

Palucka AK, Coussens LM. 2016. The basis of oncoimmunology. Cell 164: 1233-1247.

Papayannopoulos V. 2018. Neutrophil extracellular traps in immunity and disease. Nat Rev Immunol 18: 134-147.

Pardoll DM. 2012. The blockade of immune checkpoints in cancer immunotherapy. Nat Rev Cancer 12: 252-264.

Pardoll DM, Topalian SL. 1998. The role of CD4 ${ }^{+} \mathrm{T}$ cell responses in antitumor immunity. Curr Opin Immunol 10: 588-594.

Park J, Wysocki RW, Amoozgar Z, Maiorino L, Fein MR, Jorns J, Schott AF, Kinugasa-Katayama Y, Lee Y, Won NH, et al. 2016. Cancer cells induce metastasis-supporting neutrophil extracellular DNA traps. Sci Trans1 Med 8: 361 ra138.

Patel SI, Sanjana NE, Kishton RJ, Eidizadeh A, Vodnala SK, Cam M, Gartner JJ, Jia L, Steinberg SM, Yamamoto TN, et al. 2017. Identification of essential genes for cancer immunotherapy. Nature 548: 537-542.
Pylayeva-Gupta Y, Das S, Handler JS, Hajdu CH, Coffre M, Koralov SB, Bar-Sagi D. 2016. IL35-producing B cells promote the development of pancreatic neoplasia. Cancer Discov 6: 247-255.

Qian BZ, Li J, Zhang H, Kitamura T, Zhang J, Campion LR, Kaiser EA, Snyder LA, Pollard JW. 2011. CCL2 recruits inflammatory monocytes to facilitate breast-tumour metastasis. Nature 475: 222-225.

Qian BZ, Zhang H, Li J, He T, Yeo EJ, Soong DY, Carragher NO, Munro A, Chang A, Bresnick AR, et al. 2015. FLT1 signaling in metastasis-associated macrophages activates an inflammatory signature that promotes breast cancer metastasis. I Exp Med 212: 1433-1448.

Quail DF, Joyce JA. 2013. Microenvironmental regulation of tumor progression and metastasis. Nat Med 19: 1423-1437.

Queirolo P, Spagnolo F, Ascierto PA, Simeone E, Marchetti P, Scoppola A, Del Vecchio M, Di Guardo L, Maio M, Di Giacomo AM, et al. 2014. Efficacy and safety of ipilimumab in patients with advanced melanoma and brain metastases. I Neurooncol 118: 109-116.

Raulet DH. 2003. Roles of the NKG2D immunoreceptor and its ligands. Nat Rev Immunol 3: 781-790.

Raulet DH, Gasser S, Gowen BG, Deng W, Jung H. 2013. Regulation of ligands for the NKG2D activating receptor. Annu Rev Immunol 31: 413-441.

Rizvi NA, Hellmann MD, Snyder A, Kvistborg P, Makarov V, Havel JJ, Lee W, Yuan J, Wong P, Ho TS, et al. 2015. Cancer immunology. Mutational landscape determines sensitivity to PD-1 blockade in non-small cell lung cancer. Science 348: 124-128.

Roberts EW, Broz ML, Binnewies M, Headley MB, Nelson AE, Wolf DM, Kaisho T, Bogunovic D, Bhardwaj N, Krummel MF. 2016. Critical role for $\mathrm{CD}_{103}{ }^{+} / \mathrm{CD}_{141^{+}}$dendritic cells bearing CCR7 for tumor antigen trafficking and priming of T cell immunity in melanoma. Cancer Cell 30: 324-336.

Roh-Johnson M, Bravo-Cordero JJ, Patsialou A, Sharma VP, Guo P, Liu H, Hodgson L, Condeelis J. 2014. Macrophage contact induces RhoA GTPase signaling to trigger tumor cell intravasation. Oncogene 33: 4203-4212.

Rollins BJ, Sunday ME. 1991. Suppression of tumor formation in vivo by expression of the JE gene in malignant cells. Mol Cell Biol 11: 3125-3131.

Rongvaux A, Willinger T, Martinek J, Strowig T, Gearty SV, Teichmann LL, Saito Y, Marches F, Halene S, Palucka AK, et al. 2014. Development and function of human innate immune cells in a humanized mouse model. Nat Biotechnol 32: 364-372.

Rubtsov YP, Rasmussen JP, Chi EY, Fontenot J, Castelli L, Ye X, Treuting P, Siewe L, Roers A, Henderson WR Jr, et al. 2008. Regulatory $\mathrm{T}$ cell-derived interleukin-10 limits inflammation at environmental interfaces. Immunity 28: 546-558.

Ruffell B, Chang-Strachan D, Chan V, Rosenbusch A, Ho CM, Pryer N, Daniel D, Hwang ES, Rugo HS, Coussens LM. 2014. Macrophage IL-10 blocks $\mathrm{CD}^{+} \mathrm{T}$ cell-dependent responses to chemotherapy by suppressing IL-12 expression in intratumoral dendritic cells. Cancer Cell 26: 623-637.

Samraj AN, Pearce OM, Laubli H, Crittenden AN, Bergfeld AK, Banda K, Gregg CJ, Bingman AE, Secrest P, Diaz SL, et al. 2015. A red meat-derived glycan promotes inflammation and cancer progression. Proc Natl Acad Sci 112: 542-547.

Santos PM, Butterfield LH. 2018. Dendritic cell-based cancer vaccines. J Immunol 200: 443-449.

Schioppa T, Moore R, Thompson RG, Rosser EC, Kulbe H, Nedospasov S, Mauri C, Coussens LM, Balkwill FR. 2011. B regulatory cells and the tumor-promoting actions of TNF- $\alpha$ 
during squamous carcinogenesis. Proc Natl Acad Sci 108: 10662-10667.

Serrels A, Lund T, Serrels B, Byron A, McPherson RC, von Kriegsheim A, Gomez-Cuadrado L, Canel M, Muir M, Ring JE, et al. 2015. Nuclear FAK controls chemokine transcription, Tregs, and evasion of anti-tumor immunity. Cell 163: 160-173.

Shalapour S, Karin M. 2015. Immunity, inflammation, and cancer: an eternal fight between good and evil. I Clin Invest 125: 3347-3355.

Shankaran V, Ikeda H, Bruce AT, White JM, Swanson PE, Old LJ, Schreiber RD. 2001. IFN $\gamma$ and lymphocytes prevent primary tumour development and shape tumour immunogenicity. Nature 410: 1107-1111.

Shojaei F, Wu X, Zhong C, Yu L, Liang XH, Yao J, Blanchard D, Bais C, Peale FV, van Bruggen N, et al. 2007. Bv8 regulates myeloid-cell-dependent tumour angiogenesis. Nature 450: 825-831.

Shojaei F, Zhong C, Wu X, Yu L, Ferrara N. 2008. Role of myeloid cells in tumor angiogenesis and growth. Trends Cell Biol 18: 372-378.

Showalter A, Limaye A, Oyer JL, Igarashi R, Kittipatarin C, Copik AJ, Khaled AR. 2017. Cytokines in immunogenic cell death: applications for cancer immunotherapy. Cytokine 97: 123-132.

Siegel RL, Miller KD, Jemal A. 2016. Cancer statistics, 2016. CA Cancer J Clin 66: 7-30.

Snyder A, Makarov V, Merghoub T, Yuan J, Zaretsky JM, Desrichard A, Walsh LA, Postow MA, Wong P, Ho TS, et al. 2014. Genetic basis for clinical response to CTLA-4 blockade in melanoma. N Engl J Med 371: 2189-2199.

Speiser DE, Ho PC, Verdeil G. 2016. Regulatory circuits of T cell function in cancer. Nat Rev Immunol 16: 599-611.

Srivastava K, Hu J, Korn C, Savant S, Teichert M, Kapel SS, Jugold M, Besemfelder E, Thomas M, Pasparakis M, et al. 2014. Postsurgical adjuvant tumor therapy by combining antiangiopoietin-2 and metronomic chemotherapy limits metastatic growth. Cancer Cell 26: 880-895.

Steele CW, Karim SA, Leach JD, Bailey P, Upstill-Goddard R, Rishi L, Foth M, Bryson S, McDaid K, Wilson Z, et al. 2016. CXCR2 inhibition profoundly suppresses metastases and augments immunotherapy in pancreatic ductal adenocarcinoma. Cancer Cell 29: 832-845.

Sun WW, Xu ZH, Lian P, Gao BL, Hu JA. 2017. Characteristics of circulating tumor cells in organ metastases, prognosis, and $\mathrm{T}$ lymphocyte mediated immune response. Onco Targets Ther 10: 2413-2424.

Swanton C. 2012. Intratumor heterogeneity: evolution through space and time. Cancer Res 72: 4875-4882.

Taggart D, Andreou T, Scott KJ, Williams J, Rippaus N, Brownlie RJ, Ilett EJ, Salmond RJ, Melcher A, Lorger M. 2018. AntiPD-1/anti-CTLA-4 efficacy in melanoma brain metastases depends on extracranial disease and augmentation of $\mathrm{CD}^{+}$ T cell trafficking. Proc Natl Acad Sci 115: E1540-E1549.

Takahashi M, Miyazaki H, Furihata M, Sakai H, Konakahara T, Watanabe M, Okada T. 2009. Chemokine CCL2/MCP-1 negatively regulates metastasis in a highly bone marrow-metastatic mouse breast cancer model. Clin Exp Metastasis 26: $817-828$

Takeshima T, Pop LM, Laine A, Iyengar P, Vitetta ES, Hannan R. 2016. Key role for neutrophils in radiation-induced antitumor immune responses: potentiation with G-CSF. Proc Natl Acad Sci 113: 11300-11305.

Tanaka A, Sakaguchi S. 2017. Regulatory T cells in cancer immunotherapy. Cell Res 27: 109-118.
Tauriello DVF, Palomo-Ponce S, Stork D, Berenguer-Llergo A, Badia-Ramentol J, Iglesias M, Sevillano M, Ibiza S, Canellas A, Hernando-Momblona X, et al. 2018. TGF $\beta$ drives immune evasion in genetically reconstituted colon cancer metastasis. Nature 554: 538-543.

Teng MW, Galon J, Fridman WH, Smyth MJ. 2015. From mice to humans: developments in cancer immunoediting. I Clin Invest 125: 3338-3346.

Thun MJ, Henley SJ, Patrono C. 2002. Nonsteroidal anti-inflammatory drugs as anticancer agents: mechanistic, pharmacologic, and clinical issues. I Natl Cancer Inst 94: 252-266.

Tohme S, Yazdani HO, Al-Khafaji AB, Chidi AP, Loughran P, Mowen K, Wang Y, Simmons RL, Huang H, Tsung A. 2016. Neutrophil extracellular traps promote the development and progression of liver metastases after surgical stress. Cancer Res 76: 1367-1380.

Topalian SL, Hodi FS, Brahmer JR, Gettinger SN, Smith DC, McDermott DF, Powderly JD, Carvajal RD, Sosman JA, Atkins MB, et al. 2012. Safety, activity, and immune correlates of anti-PD-1 antibody in cancer. N Engl J Med 366: 2443-2454.

Topalian SL, Drake CG, Pardoll DM. 2015. Immune checkpoint blockade: a common denominator approach to cancer therapy. Cancer Cell 27: 450-461.

Tosolini M, Kirilovsky A, Mlecnik B, Fredriksen T, Mauger S, Bindea G, Berger A, Bruneval P, Fridman WH, Pages F, et al. 2011. Clinical impact of different classes of infiltrating T cytotoxic and helper cells (Th1, th2, treg, th17) in patients with colorectal cancer. Cancer Res 71: 1263-1271.

Tran E, Robbins PF, Lu YC, Prickett TD, Gartner JJ, Jia L, Pasetto A, Zheng Z, Ray S, Groh EM, et al. 2016. T-cell transfer therapy targeting mutant KRAS in cancer. $N$ Engl I Med 375: 2255-2262.

Tran Janco JM, Lamichhane P, Karyampudi L, Knutson KL. 2015. Tumor-infiltrating dendritic cells in cancer pathogenesis. I Immunol 194: 2985-2991.

Ubukata H, Motohashi G, Tabuchi T, Nagata H, Konishi S, Tabuchi T. 2010. Evaluations of interferon- $\gamma /$ interleukin-4 ratio and neutrophil/lymphocyte ratio as prognostic indicators in gastric cancer patients. J Surg Oncol 102: 742-747.

Vacchelli E, Ma Y, Baracco EE, Sistigu A, Enot DP, Pietrocola F, Yang H, Adjemian S, Chaba K, Semeraro M, et al. 2015. Chemotherapy-induced antitumor immunity requires formyl peptide receptor 1. Science 350: 972-978.

Verma B, Ritchie M, Mancini M. 2017. Development and applications of patient-derived xenograft models in humanized mice for oncology and immune-oncology drug discovery. Curr Protoc Pharmacol 78: 14.41.1-14.41.12.

Vesalainen S, Lipponen P, Talja M, Syrjanen K. 1994. Histological grade, perineural infiltration, tumour-infiltrating lymphocytes and apoptosis as determinants of long-term prognosis in prostatic adenocarcinoma. Eur J Cancer 30A: 1797-1803.

Voskoboinik I, Smyth MJ, Trapani JA. 2006. Perforin-mediated target-cell death and immune homeostasis. Nat Rev Immunol 6: 940-952.

Wagtmann N, Biassoni R, Cantoni C, Verdiani S, Malnati MS, Vitale M, Bottino C, Moretta L, Moretta A, Long EO. 1995. Molecular clones of the p58 NK cell receptor reveal immunoglobulin-related molecules with diversity in both the extraand intracellular domains. Immunity 2: 439-449.

Walker LS, Sansom DM. 2015. Confusing signals: recent progress in CTLA-4 biology. Trends Immunol 36: 63-70.

Wang Q, Feng M, Yu T, Liu X, Zhang P. 2014. Intratumoral regulatory $T$ cells are associated with suppression of colorectal carcinoma metastasis after resection through overcoming IL-17 producing T cells. Cell Immunol 287: 100-105. 
Wang TT, Zhao YL, Peng LS, Chen N, Chen W, Lv YP, Mao FY, Zhang JY, Cheng P, Teng YS, et al. 2017. Tumour-activated neutrophils in gastric cancer foster immune suppression and disease progression through GM-CSF-PD-L1 pathway. Gut 66: 1900-1911.

Ward-Hartstonge KA, Kemp RA. 2017. Regulatory T-cell heterogeneity and the cancer immune response. Clin Transl Immunology 6: e154.

Wculek SK, Malanchi I. 2015. Neutrophils support lung colonization of metastasis-initiating breast cancer cells. Nature 528: 413-417.

Weitzenfeld P, Ben-Baruch A. 2014. The chemokine system, and its CCR5 and CXCR4 receptors, as potential targets for personalized therapy in cancer. Cancer Lett 352: 36-53.

Wilgenhof S, Corthals J, Heirman C, van Baren N, Lucas S, Kvistborg P, Thielemans K, Neyns B. 2016. Phase II study of autologous monocyte-derived mRNA electroporated dendritic cells (TriMixDC-MEL) plus ipilimumab in patients with pretreated advanced melanoma. J Clin Oncol 34: 1330-1338.

Woo JR, Liss MA, Muldong MT, Palazzi K, Strasner A, Ammirante M, Varki N, Shabaik A, Howell S, Kane CJ, et al. 2014. Tumor infiltrating B-cells are increased in prostate cancer tissue. J Transl Med 12: 30.

Xue J, Schmidt SV, Sander J, Draffehn A, Krebs W, Quester I, De Nardo D, Gohel TD, Emde M, Schmidleithner L, et al. 2014. Transcriptome-based network analysis reveals a spec- trum model of human macrophage activation. Immunity 40: 274-288.

Yang C, Lee H, Jove V, Deng J, Zhang W, Liu X, Forman S, Dellinger TH, Wakabayashi M, Yu H, et al. 2013. Prognostic significance of B-cells and pSTAT3 in patients with ovarian cancer. PLoS One 8: e54029.

Yates LR, Knappskog S, Wedge D, Farmery JHR, Gonzalez S, Martincorena I, Alexandrov LB, Van Loo P, Haugland HK, Lilleng PK, et al. 2017. Genomic evolution of breast cancer metastasis and relapse. Cancer Cell 32: 169-184.e7.

Ye LY, Chen W, Bai XL, Xu XY, Zhang Q, Xia XF, Sun X, Li GG, $\mathrm{Hu} \mathrm{QD}, \mathrm{Fu} \mathrm{QH}$, et al. 2016. Hypoxia-induced epithelial-tomesenchymal transition in hepatocellular carcinoma induces an immunosuppressive tumor microenvironment to promote metastasis. Cancer Res 76: 818-830.

Zhang QW, Liu L, Gong CY, Shi HS, Zeng YH, Wang XZ, Zhao YW, Wei YQ. 2012. Prognostic significance of tumor-associated macrophages in solid tumor: a meta-analysis of the literature. PLoS One 7: e50946.

Zhao Y, Shuen TWH, Toh TB, Chan XY, Liu M, Tan SY, Fan Y, Yang H, Lyer SG, Bonney GK, et al. 2018. Development of a new patient-derived xenograft humanised mouse model to study human-specific tumour microenvironment and immunotherapy. Gutr 67: 1845-1854.

Zitvogel L, Pitt JM, Daillere R, Smyth MJ, Kroemer G. 2016. Mouse models in oncoimmunology. Nat Rev Cancer 16: 759-773. 


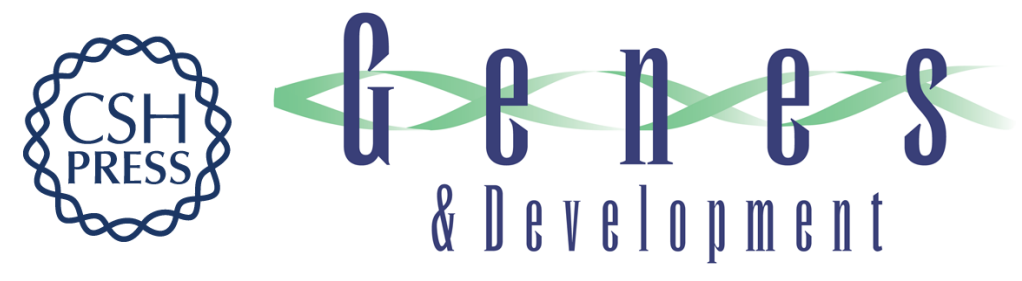

\section{Roles of the immune system in cancer: from tumor initiation to metastatic progression}

Hugo Gonzalez, Catharina Hagerling and Zena Werb

Genes Dev. 2018, 32:

Access the most recent version at doi:10.1101/gad.314617.118

\begin{tabular}{|c|c|}
\hline References & $\begin{array}{l}\text { This article cites } 234 \text { articles, } 52 \text { of which can be accessed free at: } \\
\text { http://genesdev.cshlp.org/content/32/19-20/1267.full.html\#ref-list-1 }\end{array}$ \\
\hline $\begin{array}{r}\text { Creative } \\
\text { Commons } \\
\text { License }\end{array}$ & $\begin{array}{l}\text { This article is distributed exclusively by Cold Spring Harbor Laboratory Press for the first } \\
\text { six months after the full-issue publication date (see } \\
\text { http://genesdev.cshlp.org/site/misc/terms.xhtml). After six months, it is available under a } \\
\text { Creative Commons License (Attribution-NonCommercial } 4.0 \text { International), as described } \\
\text { at http://creativecommons.org/licenses/by-nc/4.0/. }\end{array}$ \\
\hline $\begin{array}{l}\text { Email Alerting } \\
\text { Service }\end{array}$ & $\begin{array}{l}\text { Receive free email alerts when new articles cite this article - sign up in the box at the top } \\
\text { right corner of the article or click here. }\end{array}$ \\
\hline
\end{tabular}

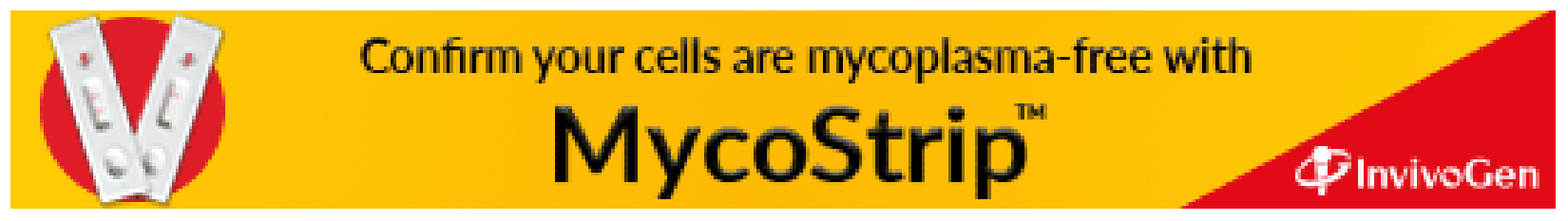

